\title{
Production, stability, gene sequencing and in situ anti-Listeria activity of mundticin KS expressed by three Enterococcus mundtii strains
}

\author{
Luca Settanni $^{\mathrm{a}, *}$, Rosa Guarcello ${ }^{\mathrm{a}}$, Raimondo Gaglio ${ }^{\mathrm{a}}$, Nicola Francesca ${ }^{\mathrm{a}}$, Aurora Aleo ${ }^{\mathrm{b}}$, \\ Giovanna E. Felis ${ }^{\mathrm{c}}$, Giancarlo Moschetti ${ }^{\mathrm{a}}$ \\ ${ }^{a}$ Department of Agricultural and Forestry Science, University of Palermo, Viale delle Scienze 4, 90128 Palermo, Italy \\ ${ }^{\mathrm{b}}$ Department of Sciences for Health Promotion and Mother-Child Care “G. D'Alessandro", University of Palermo, Palermo, Italy \\ ${ }^{\mathrm{c}}$ Department of Biotechnology, University of Verona, Strada Le Grazie 15, 37134 Verona, Italy
}

\section{A R T I C L E I N F O}

\section{Article history:}

Received 23 April 2013

Received in revised form

5 July 2013

Accepted 16 July 2013

\section{Keywords:}

Bacteriocins

Enterococcus mundtii

Food model systems

In situ activity

Listeria monocytogenes

Mundticin KS

\begin{abstract}
A B S T R A C T
Three enterococci (WFE3, WFE20 and WFE31) selected as presumptive bacteriocin producers were found to be active against Listeria monocytogenes. In this study, due to their potential industrial/food applications, the three bacterial isolates were extensively characterized. Identification was performed by means of a combined 16S rRNA gene sequencing and multiplex PCR approach, and was confirmed with the sequencing of a partial region of a protein-encoding gene, namely pheS. The three isolates belonged unequivocally to the species Enterococcus mundtii. The randomly amplified polymorphic DNA (RAPD) analysis recognized three distinct strains. The supernatants were mainly active against Listeria spp., but some lactic acid bacteria were also inhibited. The proteinaceous nature of the three supernatants was detected after treatment with proteinase $\mathrm{K}$, protease $\mathrm{B}$ and trypsin. The bacteriocins were found to be heat resistant, stable in a large $\mathrm{pH}$ range and in presence of ethanol. The bacteriocins were not adsorbed onto the surface of the producer cells and their effect was bactericidal. The production of bacteriocins was higher at neutral pHs and temperatures in the range $30-37^{\circ} \mathrm{C}$. The active supernatants did not show cytotoxicity against human erythrocytes and the three strains were susceptible to the action of common antibiotics. The genetic characterization of the bacteriocin genes showed that all three strains produced mundticin KS. They produced it in five food model systems, sterilized by thermal treatment or filtration, prepared from fresh vegetables, cereals, cheeses, meats and fishes. The in situ anti-listerial activities of the strains WFE3, WFE20 and WFE31 were quantitatively different.
\end{abstract}

(c) 2013 Elsevier Ltd. All rights reserved.

\section{Introduction}

Enterococci are considered at the crossroad of food safety (Franz, Holzapfel, \& Stiles, 1999); they are reported to be a leading cause of nosocomial infections and to have a significant role in the dissemination and persistence of antimicrobial resistance (Moellering, 1992; Murray, 1990). However, some species within this group are of relevance in food fermentation (Folquié Moreno, Rea, Cogan, \& De Vuyst, 2003) and several isolates are commonly employed as probiotics for humans and slaughter animals (Franz, Huch, Abriouel, Holzapfel, \& Gálvez, 2011). Enterococci are natural inhabitants of the intestine in warm-blooded animals (Devriese, Collins, \& Wirth, 1992), thus, they often occur in foods of animal origin (meat and cheese) (Franz et al., 1999), but they are also

\footnotetext{
* Corresponding author. Tel.: +39 091 23896043; fax: +39 0916515531.

E-mail addresses: luca.settanni@unipa.it, settanniluca@yahoo.it (L. Settanni).
}

commonly found on the above-ground parts of vegetables and cereals (Corsetti et al., 2007; Mundt \& Hammer, 1968) and may persist during the fermentation of vegetable products. Furthermore, due to their ability to resist to the technological processes used in the food industries (e.g. pasteurization and addition of acids and salt), Enterococcus spp. are usually found in many manufactured food products.

The enterococcal species most frequently identified in fermented foods are Enterococcus faecium and Enterococcus faecalis, but other species such as Enterococcus casseliflavus, Enterococcus durans and Enterococcus mundtii are common in many raw materials and foods (Corsetti et al., 2007; Franciosi, Settanni, Cavazza, \& Poznanski, 2009; Settanni et al., 2012). Besides their contribution to the organoleptic properties of fermented food products, enterococci of food interest are generally investigated for their ability to produce bacteriocins, because these protein antimicrobials produced by bacteria that enjoy a generally recognized as safe (GRAS) status may be considered as "natural" food preservatives (Settanni, 
Valmorri, Suzzi, \& Corsetti, 2008). This characteristic is of paramount importance for their application in strategies of biopreservation (Settanni \& Corsetti, 2008), that refers to the extension of the shelf-life and improvement of the safety of foods using microorganisms and/or their metabolites (Ross, Morgan, \& Hill, 2002).

In comparison to other Enterococcus species, the role of bacteriocins produced by $E$. mundtii has been scarcely studied in food systems, although their efficacy has been evaluated in mung bean sprouts (Bennik, van Overbeek, Smid, \& Gorris, 1999) and, very recently, in fresh Minas cheese (Vera Pingitore, Todorov, Sesma, \& Franco, 2012) and vacuum-packed cold smoked salmon (Bigwood et al., 2012).

The in situ antimicrobial efficacy of bacteriocin may be limited by their binding to food components (fat or protein particles) and food additives (e.g. triglyceride oils), inactivation by proteases or other inhibitors, changes in solubility and charge, changes in the cell envelope of the target bacteria (Aasen et al., 2003; Settanni et al., 2008). Furthermore, bacteriocin production can be influenced by the culture conditions (Settanni et al., 2008). It is reported that bacteriocin activities do not always correlate with cell concentration or growth rate of the producer (Kim, Hall, \& Dunn, 1997), as well as that higher levels of bacteriocin production may be obtained in sub-optimal conditions (Aasen, Moretro, Katla, Axelsson, \& Storro, 2000; Todorov \& Dicks, 2004). On the contrary, Settanni et al. (2008) found that stressing conditions and lack or low concentrations of nutritional factors determined a reduction in bacteriocin production by several $E$. mundtii strains.

This work was performed to evaluate the inhibitory activities of three E. mundtii strains, to study their production under several growth conditions and after different enzymatic, thermal and chemical treatments, to genetically investigate their structure, to determine their production in different food model systems, and to monitor their anti-Listeria potential in situ during fermentation.

\section{Materials and methods}

\subsection{Strains and growth conditions}

Enterococci (isolates WFE3, WFE20, WFE31) scored positive for antimicrobial compound production by well diffusion assay (WDA, see Section 2.3), during a general screening aimed at characterizing LAB from wheat flours (work in preparation), and E. mundtii PON10063 of flour origin were cultured in MRS (Oxoid, Basingstoke, England) for $24 \mathrm{~h}$ at $30^{\circ} \mathrm{C}$. The bacterial strains used as indicators (sensitive to the inhibitory activity) are listed in Table 1. Listeria innocua 4202 (obtained from the culture collection of National Food Biotechnology Centre, Cork, Ireland) and all Listeria monocytogenes DHPS strains (belonging to the culture collection of the Department of Sciences for Health Promotion and Mother-Child Care "G. D'Alessandro" - University of Palermo, Italy) were propagated in Brain Heart Infusion (BHI) (Oxoid) at $37^{\circ} \mathrm{C}$ for $24 \mathrm{~h}$, Lactobacillus sakei LMG 2313 (obtained from the Laboratory of Microbial Gene Technology, Ås, Norway) in modified-MRS (mMRS) (maltose and fresh yeast extract were added at final concentrations of $1 \%$ and $10 \%$, respectively, and the final $\mathrm{pH}$ was adjusted to 5.6 ) at $30{ }^{\circ} \mathrm{C}$ for $24 \mathrm{~h}$, Citrobacter freundii PSS60, Enterobacter spp. PSS11, Escherichia coli PSS2, Klebsiella oxytoca PSS82, Serratia grimesii PSS72 and Stenotrophomonas maltophilia PSS52 (belonging to the culture collection of the Agricultural Microbiology laboratory Department of Agricultural and Forestry Science - University of Palermo, Italy) were propagated in Nutrient Broth (NB) (Difco Laboratories, Detroit, MI) at $37^{\circ} \mathrm{C}$ for $24 \mathrm{~h}$, Pseudomonas putida PSS21 (of the same collection) was cultivated in NB at $20^{\circ} \mathrm{C}$ for $24 \mathrm{~h}$, while all other strains were propagated as indicated by the respective culture collection.

\subsection{Identification of enterococci at species level and strain differentiation}

The DNA from LAB cultures was extracted by the Instagene Matrix kit (Bio-Rad, Hercules, CA) as described by the manufacturer. Crude cell extracts were used as template DNA for PCR.

Genotypic identification of LAB was first carried out by $16 \mathrm{~S}$ rRNA gene sequencing. PCRs were performed as described by Weisburg, Barns, Pelletier, and Lane (1991). DNA fragments were visualized and the amplicons of about 1600 bp were purified by the QIA-quick purification kit (Qiagen S.p.a., Milan, Italy) and sequenced using the same primers employed for PCR amplification. DNA sequencing reactions were performed by PRIMM (Milan, Italy). The sequences were compared by a BLAST search in GenBank/EMBL/DDBJ database and on EzTaxon-e server (http://eztaxon-e.ezbiocloud.net/; Kim et al., 2012). The multiplex PCR assay based on sodA gene reported by Jackson, Fedorka-Cray, and Barrett (2004) was applied to confirm species identity. Finally, pheS partial sequence was obtained for strain WFE31 as previously reported (Naser et al., 2005) and compared in GenBank/EMBL/DDBJ database. DNA amplifications were performed by means of $\mathrm{T} 1$ Thermocycler (Biometra, Göttingen, Germany).

Strain differentiation was performed by random amplification of polymorphic DNA (RAPD)-PCR analysis in a $25-\mu \mathrm{L}$ reaction mix using single primers M13, AB111, and AB106 as reported by Settanni et al. (2012). PCR products were separated by electrophoresis on $2 \%$ $(w / v)$ agarose gel (Gibco BRL, Cergy Pontoise, France) and visualized by UV transillumination after staining with $S B^{\circledR}$ safe DNA gel stain (Molecular probes, Eugene, OR, USA). GeneRuler 100 bp Plus DNA ladder (M-Medical Srl, Milan, Italy) was used as a molecular size marker. RAPD patterns were analyzed using the Gelcompare II software version 6.5 (Applied-Maths, Sin Marten Latem, Belgium).

\subsection{Assays for antibacterial activity}

After propagation, the three strains WFE3, WFE20 and WFE31 were centrifuged at $10,000 \times g$ for $5 \mathrm{~min}$, washed in Ringer's solution (Sigma-Aldrich, Milan, Italy) and re-suspended in the same solution to achieve an optical density (OD) of ca. 1.00, measured by 6400 Spectrophotometer (Jenway Ltd., Felsted Dunmow, UK) at $600 \mathrm{~nm}$ wavelength, which approximately corresponds to a concentration of $10^{9} \mathrm{CFU} / \mathrm{mL}$, to standardize bacterial inocula. Cell suspensions were inoculated in MRS at a final concentration of approximately $10^{6} \mathrm{CFU} /$ $\mathrm{mL}$ and incubated at $30^{\circ} \mathrm{C}$ for $24 \mathrm{~h}$. The antimicrobial activity of the active supernatants $(20 \mu \mathrm{L})$ was tested by WDA (Schillinger \& Lücke, 1989) following the modifications of Corsetti, Settanni, and Van Sinderen (2004). L. sakei LMG 2313, L. innocua 4202 and L. monocytogenes ATCC 19114 were used as indicator strains. Inhibition was scored positive in presence of a detectable clear area around the well of the producer strain. The antibacterial activity of the supernatants was measured by the critical dilution assay of Barefoot and Klaenhammer (1983). The activity was defined as the reciprocal of the highest dilution showing definite inhibition of the indicator strain and was expressed as activity units per milliliter $(\mathrm{AU} / \mathrm{mL})$. The inhibitory substances were then characterized for their inhibitory spectra against other food related bacteria (Table 1). Tests were carried out in triplicate.

\subsection{Characterization of the active supernatants}

In order to evaluate the proteinaceous nature of the inhibitory compounds, the active supernatants, obtained after separation of the bacterial cells $(10,000 \times g$ for $5 \mathrm{~min})$ in the stationary phase of growth, were characterized for their sensitivity to proteolytic enzymes using proteinase $\mathrm{K}(12.5 \mathrm{U} / \mathrm{mg})$, protease $\mathrm{B}(45 \mathrm{U} / \mathrm{mg})$ and 
Table 1

Inhibitory spectra of E. mundtii WFE3, WFE20, and WFE31 against food-associated bacteria.

\begin{tabular}{|c|c|c|c|c|c|}
\hline \multirow[t]{2}{*}{ Strains used as indicators for the inhibition tests ${ }^{\mathrm{a}}$} & \multirow[t]{2}{*}{ Source } & \multicolumn{4}{|c|}{ Enterococcus strains tested as bacteriocin producers } \\
\hline & & PON10063 & WFE3 & WFE20 & WFE31 \\
\hline Enterococcus hirae DSM $20160^{\mathrm{T}}$ & Unknown & - & $10,666 \pm 3695 A$ & $12,800 \pm 0 \mathrm{~A}$ & $10,666 \pm 3695 A$ \\
\hline Listeria innocua 4202 & Unknown & - & $42,666 \pm 14,780 \mathrm{~A}$ & $51,200 \pm 0 A$ & $68,266 \pm 29,560 A$ \\
\hline Listeria monocytogenes ATCC 19114 & Animal tissue & - & $273,066 \pm 118,241 \mathrm{~A}$ & $51,200 \pm 0 \mathrm{~B}$ & $819,200 \pm 0 C$ \\
\hline L. monocytogenes DHPS129 & Human stool & - & $51,200 \pm 0 A$ & $34,133 \pm 14,780 A$ & $85,333 \pm 29,560 A$ \\
\hline L. monocytogenes DHPS131 & Human stool & - & $17,067 \pm 7390 A$ & $12,800 \pm 0 \mathrm{~A}$ & $34,133 \pm 14,780 \mathrm{~A}$ \\
\hline L. monocytogenes DHPS133 & Human stool & - & $204,800 \pm 0 \mathrm{~A}$ & $170,667 \pm 5920 A$ & $204,800 \pm 0 \mathrm{~A}$ \\
\hline L. monocytogenes DHPS179 & Salmon & - & $34,133 \pm 14,780 \mathrm{~A}$ & $17,067 \pm 7390 \mathrm{AB}$ & $68,266 \pm 29,560 \mathrm{AC}$ \\
\hline L. monocytogenes DHPS180 & Ricotta cheese & - & $17,067 \pm 7390 A$ & $6,400 \pm 0 A$ & $17,067 \pm 7390 \mathrm{~A}$ \\
\hline L. monocytogenes DHPS182 & Ricotta cheese & - & $25,600 \pm 0 \mathrm{~A}$ & $68,266 \pm 29,560 A$ & $34,133 \pm 14,780 \mathrm{~A}$ \\
\hline L. monocytogenes DHPS184 & Rice salad & - & $85,333 \pm 29,560 \mathrm{~A}$ & $34,133 \pm 14,780 \mathrm{AB}$ & $136,533 \pm 59,120 \mathrm{AC}$ \\
\hline L. monocytogenes DHPS185 & Beef & - & $136,533 \pm 59,120 \mathrm{~A}$ & $136,533 \pm 59,120 A$ & $136,533 \pm 59,120 A$ \\
\hline L. monocytogenes DHPS186 & Mozzarella salad & - & $85,333 \pm 29,560 A$ & $25,600 \pm 0 \mathrm{BC}$ & $68,266 \pm 29,560 \mathrm{AC}$ \\
\hline L. monocytogenes DHPS187 & Roasted chicken & - & $170,667 \pm 5920 A$ & $546,133 \pm 236,483 B$ & $409,600 \pm 0 B$ \\
\hline L. monocytogenes DHPS188 & Green salad & - & $204,800 \pm 0 \mathrm{~A}$ & $68,266 \pm 29,560 \mathrm{~B}$ & $68,266 \pm 29,560 \mathrm{~B}$ \\
\hline L. monocytogenes DHPS1BO & Chopped meat & - & $68,266 \pm 29,560 \mathrm{~A}$ & $17,067 \pm 7390 \mathrm{BC}$ & $21,333 \pm 7390 A C$ \\
\hline L. monocytogenes DHPS2BO & Fresh salami & - & $68,266 \pm 29,560 A$ & $12,800 \pm 0 \mathrm{~B}$ & $17,067 \pm 7390 \mathrm{~B}$ \\
\hline L. monocytogenes DHPS3BO & Fresh salami & - & $6400 \pm 0 \mathrm{~A}$ & $17,067 \pm 7390 \mathrm{AC}$ & $25,600 \pm 0 B C$ \\
\hline L. monocytogenes DHPS4BO & Ripened salami & - & $68,266 \pm 29,560 A$ & $5333 \pm 1847 \mathrm{~B}$ & $17,067 \pm 7390 \mathrm{~B}$ \\
\hline L. monocytogenes DHPS5BO & Ripened salami & - & $17,067 \pm 7390 A$ & $17,067 \pm 7390 A$ & $25,600 \pm 0 \mathrm{~A}$ \\
\hline L. monocytogenes DHPS6BO & Ripened salami & - & $17,067 \pm 7390 A$ & $17,067 \pm 7390 A$ & $17,067 \pm 7390 A$ \\
\hline L. monocytogenes DHPS7BO & Ripened salami & - & $17,067 \pm 7390 A$ & $6,400 \pm 0 A$ & $10,667 \pm 3695 A$ \\
\hline L. monocytogenes DHPS11BO & Meat factory & - & $12,800 \pm 0 \mathrm{~A}$ & $12,800 \pm 0 \mathrm{~A}$ & $12,800 \pm 0 \mathrm{~A}$ \\
\hline L. monocytogenes DHPS12BO & Ripened salami & - & $12,800 \pm 0 \mathrm{~A}$ & $6,400 \pm 0 \mathrm{AB}$ & $34,133 \pm 14,780 \mathrm{AC}$ \\
\hline L. monocytogenes DHPS13BO & Gorgonzola cheese & - & $12,800 \pm 0 \mathrm{~A}$ & $12,800 \pm 0 \mathrm{~A}$ & $17,067 \pm 7390 \mathrm{~A}$ \\
\hline L. monocytogenes DHPS20BO & Gorgonzola cheese & - & $204,800 \pm 0 \mathrm{~A}$ & $17,067 \pm 7390 \mathrm{~B}$ & $25,600 \pm 0 \mathrm{~B}$ \\
\hline L. monocytogenes DHPS22BO & Taleggio cheese & - & $68,266 \pm 29,560 A$ & $34,133 \pm 14,780 \mathrm{~A}$ & $51,200 \pm 0 A$ \\
\hline L. monocytogenes DHPS24BO & Taleggio cheese & - & $25,600 \pm 0 \mathrm{~A}$ & $17,067 \pm 7,390 \mathrm{AB}$ & $68,266 \pm 29,560 \mathrm{AC}$ \\
\hline Lactobacillus farciminis DSM 20180 & Sausage & - & $1600 \pm 0 \mathrm{~A}$ & $1066 \pm 462 B$ & $800 \pm 0 C$ \\
\hline Lactobacillus curvatus ssp. curvatus ATCC $25601^{\mathrm{T}}$ & Milk & - & $1066 \pm 462 \mathrm{~A}$ & $200 \pm 0 \mathrm{~B}$ & $167 \pm 58 \mathrm{~B}$ \\
\hline Lactobacillus delbrueckii ssp. bulgaricus ATCC $11842^{\mathrm{T}}$ & Yogurt & - & $667 \pm 231 \mathrm{~A}$ & $200 \pm 0 \mathrm{~B}$ & $400 \pm 0 C$ \\
\hline Lactobacillus fermentum DSM 20391 & Unknown & - & $1066 \pm 462 \mathrm{~A}$ & $400 \pm 0 \mathrm{~B}$ & $667 \pm 231 C$ \\
\hline Lactobacillus paralimentarius DSM $13238^{\mathrm{T}}$ & Sourdough & - & $3200 \pm 0 \mathrm{~A}$ & $800 \pm 0 \mathrm{~B}$ & $2,133 \pm 924 \mathrm{~A}$ \\
\hline Lactobacillus paraplantarum DSM $10667^{\mathrm{T}}$ & Beer & - & $333 \pm 115 A$ & $200 \pm 0 \mathrm{~A}$ & $133 \pm 58 \mathrm{~A}$ \\
\hline Lactobacillus pentosus ATCC $8041^{\mathrm{T}}$ & Unknown & - & $800 \pm 0 A$ & $167 \pm 58 \mathrm{~B}$ & $533 \pm 231 \mathrm{~A}$ \\
\hline Lactobacillus pentosus DSM 20199 & Unknown & - & $8533 \pm 3695 A$ & $1333 \pm 462 B$ & $2667 \pm 924 \mathrm{~B}$ \\
\hline Leuconostoc mesenteroides DSM $20343^{\mathrm{T}}$ & Fermented olives & - & $25,600 \pm 0 \mathrm{~A}$ & $6400 \pm 0 B$ & $8533 \pm 3695 B$ \\
\hline Pediococcus acidilactici LMG $11384^{\mathrm{T}}$ & Barley & - & $2667 \pm 924 A$ & $667 \pm 231 \mathrm{AB}$ & $1333 \pm 462 A C$ \\
\hline \multicolumn{6}{|l|}{ Statistical significance: } \\
\hline Strains & & ns & $* * *$ & $* * *$ & $* * *$ \\
\hline
\end{tabular}

The results are expressed in activity units $(\mathrm{AU}) / \mathrm{mL}$ and indicate mean value $\pm \mathrm{SD}$ of three replicates. The activity was measured in MRS supernatants.

- , no inhibition.

$P$ value: ${ }^{*}, P \leq 0.05 ;{ }^{* *}, P \leq 0.01 ;{ }^{* * *}, P \leq 0.001 ;$ ns $=$ not significant.

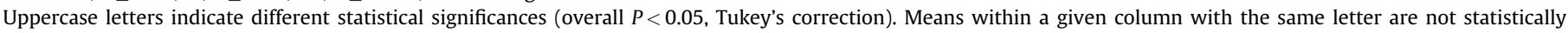
different from each other.

${ }^{a}$ The following strains were not inhibited by any active supernatant: Citrobacter freundii PSS60, Enterococcus durans DSM $20633^{\mathrm{T}}$, Enterococcus faecium DSM $20477^{\mathrm{T}}$,

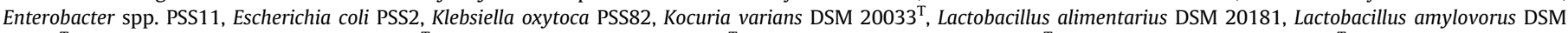

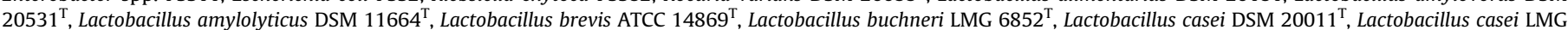

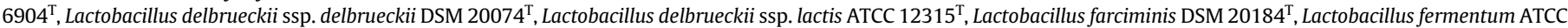

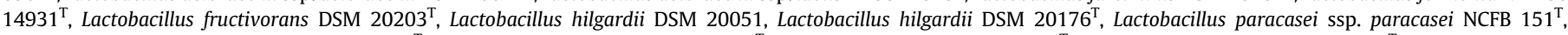

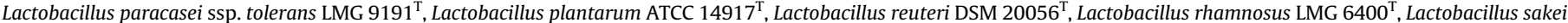

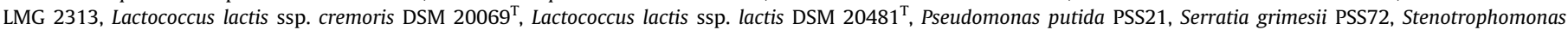
maltophilia PSS52, Streptococcus thermophilus DSM $20617^{\mathrm{T}}$.

trypsin $(10.6 \mathrm{U} / \mathrm{mg})$ at a final concentration of $1 \mathrm{mg} / \mathrm{mL}$ in phosphate buffer ( $\mathrm{pH}$ 7.0). All enzymes were purchased from SigmaAldrich (Milan, Italy). The supernatants were incubated for $2 \mathrm{~h}$ at $37^{\circ} \mathrm{C}$ and the remaining activity was determined by well diffusion assay (WDA) (Settanni, Massitti, Van Sinderen, \& Corsetti, 2005). The effect of $\alpha$-amylase and lipase, heat treatment, $\mathrm{pH}$ and organic solvent on the antimicrobial activity was evaluated as described by Corsetti, Settanni, Braga, Lopes, and Suzzi (2008). Tests were carried out in triplicate.

\subsection{Adsorption studies and effect of bacteriocins}

The effect of the $\mathrm{pH}$ on the adsorption of the active proteins onto producer cells was evaluated as reported by Todorov et al. (1999) and Yang, Johnson, and Ray (1992).
The effect of the antimicrobial compounds on the sensitive cells was evaluated as follows: the supernatants $(4 \mathrm{~mL})$ were adjusted to pH 6.5, treated with catalase as reported by Corsetti et al. (2008) and concentrated under vacuum (Hetovac VR-1, Heto Lab Equipment, Birkerod, Denmark); the dried supernatants were re-suspended into $4 \mathrm{~mL}$ of BHI and filtered through a $0.22-\mu \mathrm{m}$ pore size filter (Millipore); the indicator strain (L. monocytogenes ATCC 19114) was inoculated at a cellular concentration of approximately $10^{3} \mathrm{CFU} / \mathrm{mL}$. If no growth of $L$. monocytogenes ATCC 19114 occurred in presence of the bacteriocins, the cells were recovered and transferred into BHI to distinguish between bactericidal and bacteriostatic effect. The supernatant of E. mundtii PON10063, treated as above described, was used as negative control. Cell suspensions were followed by measuring the OD at $600 \mathrm{~nm}$ at $T_{0}$, when the supernatants were added, 2 -h intervals for the first $10 \mathrm{~h}$ and then at $24 \mathrm{~h}$ for seven days.

Tests were carried out in triplicate. 


\subsection{Bacteriocin production at different incubation temperatures and initial growth $\mathrm{pH}$ values}

To evaluate the effect of temperature and $\mathrm{pH}$ on the production of bacteriocins. Cells of the producer strains were cultivated at 15 , 30,37 and $45^{\circ} \mathrm{C}$ in MRS. Incubation was for $48 \mathrm{~h}$, except for the assay at $15^{\circ} \mathrm{C}$ that was prolonged for five days. The effect of the initial $\mathrm{pH}$ of medium was evaluated by adjusting MRS to $\mathrm{pH} 4.0,5.0$, $6.0,7.0,8.0$ and 9.0 with $5 \mathrm{M} \mathrm{NaOH}$ or $5 \mathrm{M} \mathrm{HCl}$. Incubation was at $30{ }^{\circ} \mathrm{C}$ for $48 \mathrm{~h}$. Tests were carried out in triplicate.

\subsection{Evaluation of cellular toxicity}

Cellular toxicity of the three active supernatants was assayed following the methodology reported by Xian-guo and Ursula (1994). Each sample $(0.8 \mathrm{~mL})$ was placed in a microcentrifuge tube and the final volume of $1 \mathrm{~mL}$ was reached adding human erythrocytes. Phosphate buffer saline (PBS) (Oxoid) and tap water were used as negative and positive control, respectively. The tubes were incubated at $37{ }^{\circ} \mathrm{C}$ for $30 \mathrm{~min}$ and hemolysis was observed after centrifugation at $3000 \times g$ for $5 \mathrm{~min}$. Hemolysis was scored positive when the erythrocytes did not form a pellet after centrifugation.

\subsection{Evaluation of antibiotic resistance}

The antibiotic resistance of $E$. mundtii strains was tested according to the guidelines of the Clinical and Laboratory Standards Institute (2011) (CLSI) for enterococci, applying the Performance Standards for Antimicrobial Susceptibility Testing. According to those recommendations, the following antibiotics were assayed by the disk diffusion test: penicillin (10 units) and ampicillin (10 $\mu \mathrm{g})$ for the "group A primary test and report"; quinupristin-dalfopristin $(15 \mu \mathrm{g})$, linezolid $(30 \mu \mathrm{g})$ and vancomycin $(30 \mu \mathrm{g})$ for the "group B primary test report selectively".

\subsection{Amplification, cloning and sequencing of bacteriocin-coding genes}

The structural genes for bacteriocin production were analyzed by PCR amplification using primers mapping on the nucleotide sequence of $E$. mundtii bacteriocin-coding genes. Genomic DNA from E. mundtii WFE3, WFE20 and WFE31 were used as templates for amplification with the primer pair Mnt-1F (5'-TGAGAGAAGGTTTAAGTTTTGAAGAA-3')/Mnt-1R (5'-TCCACTGAAATCCATGAATGA-3') mapping upstream of the coding sequence of known bacteriocins KS (Kawamoto et al., 2002), CRL35 (Saavedra, Minahk, de Ruiz Holgado, \& Sesma, 2004), QU2 (Zendo et al., 2005) and MunL (Feng, Guron, Churey, \& Worobo, 2009), applying the conditions described by Zendo et al. (2005). DNA from E. mundtii PON10063 was used as negative control in PCRs. PCR products were analyzed on $1.5 \%(w / v)$ agarose gel and visualized as above reported.

Amplicons generated with the primer pair Mnt-1F/Mnt-1R were purified by QIA-quick purification kit (Qiagen) and cloned into the pGEM $^{\circledR}$-T Easy Vector (Promega, Milan, Italy) following manufacturer's instructions. Ligation products were transformed into $E$. coli JM109 high efficiency competent cells and these were plated onto Luria-Bertani (LB) agar (Oxoid) containing $100 \mu \mathrm{g} / \mathrm{mL}$ ampicillin (Sigma-Aldrich), X-Gal (5-bromo-4-chloro-3-indolyl- $\beta$-D-galactopyranoside, $80 \mu \mathrm{g} / \mathrm{mL}$ ) and IPTG (isopropyl- $\beta$-D-thiogalactopyranoside, $0.5 \mathrm{mM}$ ) (Eppendorf, Milan, Italy). Recombinant white colonies were screened by colony-PCR using vector specific primers SP6 ( $5^{\prime}-$ ATTTAGGTGACACTATAGAATAC- $\left.3^{\prime}\right)$ and T7 (5'-TAATACGACTCAC TATAGGG-3' $3^{\prime}$ in a $25-\mu \mathrm{L}$ reaction mix applying the following amplification program: $94{ }^{\circ} \mathrm{C}$ for $5 \mathrm{~min}, 4^{\circ} \mathrm{C}$ for $4 \mathrm{~min}, 35$ cycles at $94^{\circ} \mathrm{C}$ for
$30 \mathrm{~s}, 52{ }^{\circ} \mathrm{C}$ for $30 \mathrm{~s}$ and $72{ }^{\circ} \mathrm{C}$ for $50 \mathrm{~s}$, followed by a final extension at $72{ }^{\circ} \mathrm{C}$ for $5 \mathrm{~min}$. Insert integrity was confirmed by a nestedamplification with Mnt-1F and Mnt-1R primers using purified colony-PCR amplicons as templates and the previously described amplification program. In addition, T7/Mnt-1F and T7/Mnt-1 $\mathrm{R}$ primer pairs were alternatively employed in a different nested-PCR ( 35 cycles at $94{ }^{\circ} \mathrm{C}$ for $30 \mathrm{~s}, 52{ }^{\circ} \mathrm{C}$ for $30 \mathrm{~s}$ and $72{ }^{\circ} \mathrm{C}$ for $40 \mathrm{~s}$, followed by a final extension at $72{ }^{\circ} \mathrm{C}$ for $2 \mathrm{~min}$ ) to determine the orientation of fragments into the cloning vector. PCR products were separated by electrophoresis in a $1.5 \%(w / v)$ agarose gel, stained with SYBR ${ }^{\circledR}$ safe DNA gel.

Sequencing reactions were performed by PRIMM and the sequences were compared by a BLAST search in GenBank/EMBL/DDBJ database. The prediction of the open reading frame (ORF) was performed with the softwares ChromasPro v1.6 (Copyright 20032012 Technelysium Pty Ltd. Biotech Works Inc.) and pDRAW32 v1.1.114 (www.acaclone.com). The ClustalX program (Thompson, Gibson, Plewniak, Jeanmougin, \& Higgins, 1997) was used for nucleotide sequence analysis. Sequence alignments were analyzed and adjusted by GeneDoc program v2.5.000 (K.B. Nicholas and H.B. Nicholas, unpublished data).

\subsection{Amplification of enterocin CRL35 biosynthetic cluster}

The DNA from the strains WFE3, WFE20 and WFE31 were amplified with the primer pair mun1F (5'-GCAAACCGATAAGAA TGTGGGAT-3')/mun7R (5'-TATACATTGTCCCCACAACC-3') (Saavedra et al., 2004), designed to amplify the biosynthetic cluster of enterocin CRL35 that has been shown to share high sequence identity with the cluster of mundticin KS. The amplification program included: denaturation at $94^{\circ} \mathrm{C}$ for $3 \mathrm{~min}, 30$ cycles at $94^{\circ} \mathrm{C}$ for $30 \mathrm{~s}, 55^{\circ} \mathrm{C}$ for $30 \mathrm{~s}$ and $72{ }^{\circ} \mathrm{C}$ for $3 \mathrm{~min}$ and $40 \mathrm{~s}$, followed by a final extension at $72{ }^{\circ} \mathrm{C}$ for 4 min. DNA from $E$. mundtii PON10063 was used as negative control in PCRs. PCR products were analyzed on $1 \%(w / v)$ agarose gel and visualized.

\subsection{Bacteriocin production in food model systems}

In order to evaluate the effect of different food components on the inhibitory activity of the E. mundtii strains, five food model systems [vegetable broth (VB), meat broth (MB), fish broth (FB), cereal broth $(\mathrm{CeB})$ and cheese broth $(\mathrm{ChB})$ ] were developed: VB with carrot $(50 \mathrm{~g} / \mathrm{L})$, tomato $(50 \mathrm{~g} / \mathrm{L})$, zucchini $(50 \mathrm{~g} / \mathrm{L})$ and celery (50 g/L); MB with pork (50 g/L), calf (50 g/L), chicken $(50 \mathrm{~g} / \mathrm{L})$ and sheep $(50 \mathrm{~g} / \mathrm{L})$ meat; FB with salmon $(50 \mathrm{~g} / \mathrm{L})$, octopus $(50 \mathrm{~g} / \mathrm{L})$, anchovy $(50 \mathrm{~g} / \mathrm{L})$ and cod $(50 \mathrm{~g} / \mathrm{L})$; CeB with wheat bran $(50 \mathrm{~g} / \mathrm{L})$, wheat $(50 \mathrm{~g} / \mathrm{L})$, barley $(50 \mathrm{~g} / \mathrm{L})$ and rice $(50 \mathrm{~g} / \mathrm{L})$ kernels; ChB with Caciocavallo (50 g/L), Parmigiano (50 g/L), Pecorino $(50 \mathrm{~g} / \mathrm{L})$ and Vastedda ( $50 \mathrm{~g} / \mathrm{L}$ ) cheeses. The preparation of the five broths was as follows: all four ingredients of each broth were homogenized with a Sorvall Omni-Mixer (Dupont Instruments, Newtown, CT) at the maximum speed for $1 \mathrm{~min}$, transferred to a Schott Duran bottle, added with distilled $\mathrm{H}_{2} \mathrm{O}(1 \mathrm{~L})$, left under magnetic stirring for $1 \mathrm{~h}$ and centrifuged at $10,000 \times g$ for $5 \mathrm{~min}$. Each supernatant was divided in two aliquots: one was sterilized by autoclaving at $121^{\circ} \mathrm{C}$ for $20 \mathrm{~min}$ (autoclaved broths), while the other aliquot was filter $(0.20-\mu \mathrm{m}$ pore size filter, Sartorius, Aubagne Cedex, France) sterilized (filtered broths). The broths were subjected to the measurement of $\mathrm{pH}$, determined electrometrically using the $\mathrm{pH}$ meter BASIC $20+$ (Crison Instrument S.A., Barcelona, Spain), and water activity $\left(a_{w}\right)$, obtained with the AquaLab vapor sorption analyzer (Decagon Devices, Pullman, WA, USA).

Autoclaved and filtered broths were inoculated singly with the strains WFE3, WFE20 and WFE31 as above reported (Section 2.3) at a final concentration of approximately $10^{6} \mathrm{CFU} / \mathrm{mL}$, after cell 
washing. MRS was also inoculated as control trial. E. mundtii PON10063 was used as negative control. Incubation was at $30^{\circ} \mathrm{C}$ for $24 \mathrm{~h}$. Tests were carried out in triplicate.

\subsection{In situ activity of $E$. mundtii strains against L. monocytogenes}

To evaluate the potential of the bacteriocin producing strains during the fermentation of different foods, the five food model systems were inoculated with dual combinations Enterococcus/ L. monocytogenes. Tests in MRS were carried out for comparison. All strains were prepared as reported in Section 2.3. The Enterococcus strains were inoculated at the final concentration of approximately $10^{6} \mathrm{CFU} / \mathrm{mL}$ to act as starter cultures, while L. monocytogenes ATCC 19114 at about $10^{4} \mathrm{CFU} / \mathrm{mL}$ to simulate a massive contamination. E. mundtii PON10063 was used as negative control. Incubation was at $30^{\circ} \mathrm{C}$ for five days to mimic a common food fermentation process. Plate counts were performed to enumerate the surviving cells. The broths $(1 \mathrm{~mL})$ were subjected to the serial decimal dilution in Ringer's solution and the cell suspensions were spread plated $(0.1 \mathrm{~mL})$ and incubated as follows: on kanamycin aesculin azide (KAA) agar (Oxoid), incubated aerobically at $37{ }^{\circ} \mathrm{C}$ for $24 \mathrm{~h}$, for Enterococcus; on Listeria Selective Agar Base (LSAB) (Oxoid) supplemented with SR0140E (Oxford formulation), incubated aerobically at $37^{\circ} \mathrm{C}$ for $48 \mathrm{~h}$, for $L$. monocytogenes. In order to verify the specificity of the media employed, the absence of growth of enterococci on LSAB and that of $L$. monocytogenes on KAA were verified prior in situ activity determination. Tests were carried out in duplicate.

\subsection{Statistical analyses}

Data of inhibitory activities, effect of enzyme, $\mathrm{pH}$, temperature and organic solvent treatments on bacteriocins, production of bacteriocins under different $\mathrm{pH}$ and temperature conditions and production of bacteriocins in different food models were statistically analyzed using the generalized linear model (GLM) procedure, including the effects of strain, with the program SAS 2008 - version 9.2 (Statistical Analysis System Institute Inc., Cary, NC, USA). The Student " $t$ " test was used for mean comparison. The post-hoc Tukey method was applied for pairwise comparison.

The in situ anti-Listeria efficacy of bacteriocins was analyzed by the Student " $t$ " test and post-hoc Tukey method. Significance level was $P<0.05$.

\section{Results}

\subsection{Genotypic identification and differentiation of enterococci}

The isolates WFE3, WFE20 and WFE31 were identified as E. mundtii by $16 \mathrm{~S}$ rRNA gene sequencing, and the gene sequences were deposited in GenBank under the Acc. No. KC291248KC291250. Species identification was confirmed by using a specific multiplex PCR system developed to distinguish among E. mundtii, Enterococcus flavescens and Enterococcus sulfureus (results not shown) and with partial sequencing of pheS gene for WFE31, which confirmed the identification as E. mundtii (data not shown).

RAPD-PCR analysis (Fig. 1) recognized the three isolates as three distinct strains.

\subsection{Bacteriocin production}

E. mundtii WFE3, WFE20, and WFE31 were active against several bacterial strains (Table 1 ). All three Enterococcus strains inhibited the same sensitive strains, but the inhibitory effect was strain dependent, since different activities $(P<0.05)$, expressed in $\mathrm{AU} / \mathrm{mL}$ were

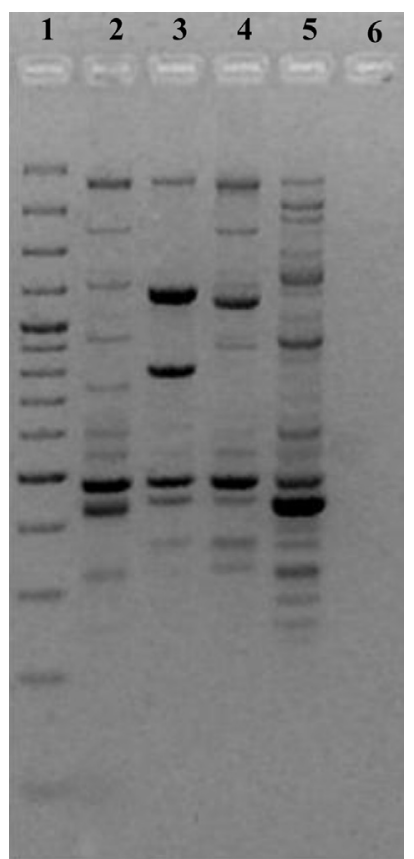

Fig. 1. RAPD-PCR profiles obtained with primer M13. Lanes: 1 , GeneRuler 100 bp Plus DNA ladder (M-Medical); 2, E. mundtii WFE3; 3, E. mundtii WFE20; 4, E. mundtii WFE31; 5, E. mundtii PON10063; 6, PCR negative control.

registered. The highest inhibitions of all three supernatants were detected against $L$. monocytogenes strains: all 25 indicator strains belonging to this species and isolated from different sources resulted sensitive. E. mundtii WFE3 and WFE20 were less active than strain WFE31. No big differences in terms of inhibitory power $(P>0.05)$ were found among the three strains against Enterococcus hirae DSM $20160^{\mathrm{T}}$, L. innocua 4202, Lactobacillus paraplantarum DSM $10667^{\mathrm{T}}$ and Pediococcus acidilactici LMG $11384^{\mathrm{T}}$. Gram-negative bacteria were not inhibited by any of the active supernatants.

\subsection{Effect of different treatments on the antibacterial activity}

The antibacterial compounds were all inactivated by proteolytic enzymes (Table 2), confirming their proteinaceous nature. The three presumptive bacteriocins were insensitive to $\alpha$-amylase and lipase. Heat treatment progressively reduced the inhibitory activities of the supernatants; the inhibition was completely lost after the sterilization of supernatants. All three bacteriocins retained almost the full activity at the different $\mathrm{pH}$ and concentration of ethanol tested. After treatment with $\alpha$-amylase and lipase and exposure at $\mathrm{pH} 10.0$ and 11.0, the supernatants from the strains WFE3 and WFE20 showed comparable activities $(P<0.05)$ against L. monocytogenes ATCC 19114, while the treatment at $100{ }^{\circ} \mathrm{C}$ determined a decrease of WFE31 activity which was at the same level $(P>0.05)$ to that of WFE3.

\subsection{Absorption to the producing cells and effect of the bacteriocins}

The bacteriocins of E. mundtii WFE3, WFE20, and WFE31 were not absorbed by the cell surface. The effect of the active supernatants was followed for seven days (Fig. 2). During this period the growth of L. monocytogenes ATCC 19114 was completely inhibited by the addition of all three supernatants. After test, the cells were recovered from the bacteriocin-containing broths and transferred into bacteriocin-free BHI. Since no growth of $L$. monocytogenes ATCC 
Table 2

Effect of enzymes, heat treatment, $\mathrm{pH}$, and organic solvent on the inhibitory activity of $E$. mundtii WFE3, WFE20, and WFE31.

\begin{tabular}{|c|c|c|c|c|}
\hline \multirow[t]{2}{*}{ Treatment } & \multicolumn{4}{|c|}{ Enterococcus strains } \\
\hline & PON10063 & WFE3 & WFE20 & WFE31 \\
\hline Control (supernatant not treated) & - & $273,066 \pm 118,241 \mathrm{~A}$ & $51,200 \pm 0 B$ & $819,200 \pm 0 C$ \\
\hline \multicolumn{5}{|l|}{ Enzymes: } \\
\hline Proteinase K & - & - & - & - \\
\hline Protease B & - & - & - & - \\
\hline Trypsin & - & - & - & - \\
\hline$\alpha$-amylase & - & $85,333 \pm 29,560 \mathrm{~A}$ & $42,667 \pm 14,780 A$ & $819,200 \pm 0 B$ \\
\hline Lipase & - & $85,333 \pm 29,560 \mathrm{~A}$ & $51,200 \pm 0 A$ & $682,667 \pm 236,483 B$ \\
\hline \multicolumn{5}{|l|}{ Statistical significance: } \\
\hline Strains & & $* * *$ & $* * *$ & $* * *$ \\
\hline \multicolumn{5}{|l|}{ Heat treatment: } \\
\hline $100{ }^{\circ} \mathrm{C}$ for $20 \mathrm{~min}$ & - & $68,267 \pm 29,560 \mathrm{~A}$ & $25,600 \pm 0 \mathrm{~B}$ & $170,667 \pm 59,120 \mathrm{~A}$ \\
\hline $100^{\circ} \mathrm{C}$ for $60 \mathrm{~min}$ & - & $25,600 \pm 0 A$ & $10,667 \pm 3695 B$ & $42,667 \pm 14,780 \mathrm{C}$ \\
\hline $121^{\circ} \mathrm{C}$ for $15 \mathrm{~min}$ & - & - & - & - \\
\hline \multicolumn{5}{|l|}{ Statistical significance: } \\
\hline Strains & & $* *$ & $* * *$ & $* *$ \\
\hline \multicolumn{5}{|l|}{$\mathrm{pH}:$} \\
\hline 3.0 & - & $170,667 \pm 59,120 \mathrm{~A}$ & $25,600 \pm 0 B$ & $682,667 \pm 236,483 C$ \\
\hline 4.0 & - & $204,800 \pm 0 A$ & $25,600 \pm 0 \mathrm{~B}$ & $819,200 \pm 0 C$ \\
\hline 5.0 & - & $170,667 \pm 59,120 \mathrm{~A}$ & $21,333 \pm 7390 B$ & $819,200 \pm 0 C$ \\
\hline 6.0 & - & $102,400 \pm 0 A$ & $25,600 \pm 0 \mathrm{~B}$ & $819,200 \pm 0 C$ \\
\hline 7.0 & - & $102,400 \pm 0 A$ & $21,333 \pm 7390 \mathrm{~B}$ & $682,667 \pm 236,483 C$ \\
\hline 8.0 & - & $51,200 \pm 0 A$ & $25,600 \pm 0 \mathrm{~B}$ & $819,200 \pm 0 C$ \\
\hline 9.0 & - & $42,667 \pm 14,780 \mathrm{~A}$ & $17,067 \pm 7390 \mathrm{~B}$ & $682,667 \pm 236,483 C$ \\
\hline 10.0 & - & $25,600 \pm 14,780 \mathrm{~A}$ & $12,800 \pm 0 \mathrm{~A}$ & $409,600 \pm 0 \mathrm{~B}$ \\
\hline 11.0 & - & $25,600 \pm 0 A$ & $12,800 \pm 0 \mathrm{~A}$ & $341,333 \pm 118,241 B$ \\
\hline \multicolumn{5}{|l|}{ Statistical significance: } \\
\hline Strains & & $* * *$ & $* *$ & $* * *$ \\
\hline \multicolumn{5}{|l|}{ Organic solvent: } \\
\hline $\mathrm{C}_{2} \mathrm{H}_{5} \mathrm{OH} 5 \%$ & - & $102,400 \pm 0 A$ & $25,600 \pm 0 B$ & $341,333 \pm 118,241 C$ \\
\hline $\mathrm{C}_{2} \mathrm{H}_{5} \mathrm{OH} 10 \%$ & - & $85,333 \pm 29,560 \mathrm{~A}$ & $25,600 \pm 0 B$ & $204,800 \pm 0 C$ \\
\hline $\mathrm{C}_{2} \mathrm{H}_{5} \mathrm{OH} 15 \%$ & - & $85,333 \pm 29,560 \mathrm{~A}$ & $25,600 \pm 0 B$ & $204,800 \pm 0 C$ \\
\hline \multicolumn{5}{|l|}{ Statistical significance: } \\
\hline Strains & & ns & ns & ns \\
\hline
\end{tabular}

The results are expressed in activity units $(\mathrm{AU}) / \mathrm{mL}$ and indicate mean value $\pm \mathrm{SD}$ of three replicates. The activity was measured in MRS supernatants.

- , no inhibition

All assays were carried out against L. monocytogenes ATCC 19114.

$P$ value: ${ }^{*}, P \leq 0.05$; ${ }^{* *}, P \leq 0.01 ;{ }^{* * *}, P \leq 0.001$; ns $=$ not significant

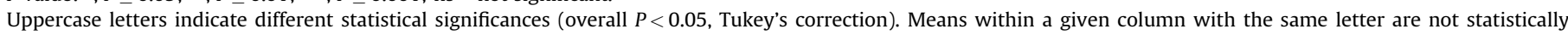
different from each other.

19114 was observed after incubation at the optimal temperature, the effect of the three bacteriocins, at the tested concentrations, was assumed to be bactericidal. However, these observations cannot exclude a bacteriostatic behavior at lower concentrations of bacteriocins. The supernatant from E. mundtii PON10063 did not show inhibitory effect, in fact, in its presence, the growth curve of the indicator strain was almost superimposable to that obtained without any addition of concentrated supernatant.

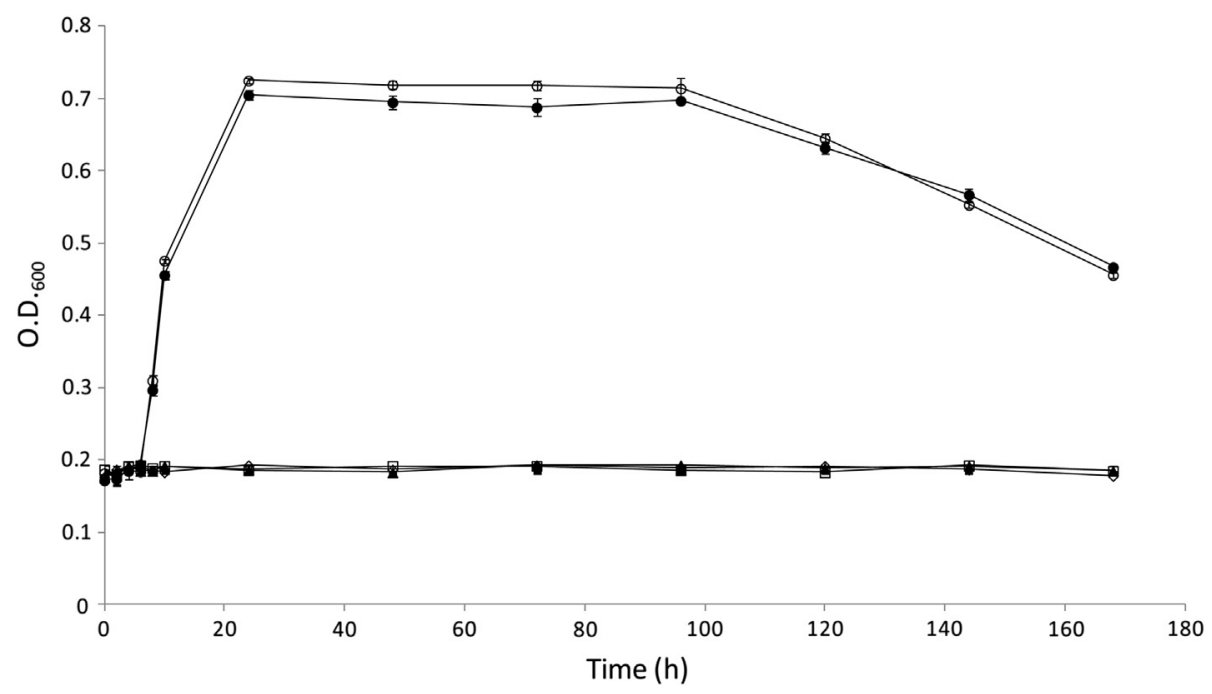

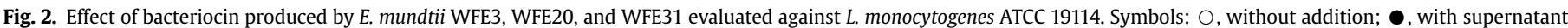

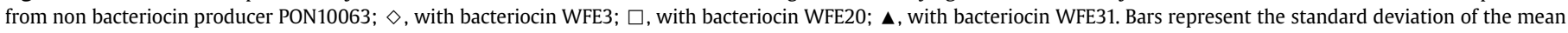
value. Bars not visible are smaller than symbol size. 
Table 3

Effect of different growth conditions on the inhibitory activity of E. mundtii WFE3, WFE20, and WFE31.

\begin{tabular}{|c|c|c|c|c|}
\hline \multirow[t]{2}{*}{ Treatment } & \multicolumn{4}{|c|}{ Enterococcus strains } \\
\hline & PON10063 & WFE3 & WFE20 & WFE31 \\
\hline Control $^{\mathrm{a}}$ & - & $273,066 \pm 118,241 \mathrm{~A}$ & $51,200 \pm 0 B$ & $819,200 \pm 0 C$ \\
\hline \multicolumn{5}{|c|}{ Temperature: } \\
\hline $15^{\circ} \mathrm{C}$ & - & $204,800 \pm 0 A$ & $25,600 \pm 0 \mathrm{~B}$ & $682,667 \pm 236,483 C$ \\
\hline $37^{\circ} \mathrm{C}$ & - & $204,800 \pm 0 A$ & $34,133 \pm 14,780 \mathrm{~B}$ & $819,200 \pm 0 C$ \\
\hline $45^{\circ} \mathrm{C}$ & - & $170,667 \pm 59,121 \mathrm{~A}$ & $25,600 \pm 0 B$ & $409,600 \pm 0 C$ \\
\hline \multicolumn{5}{|c|}{ Statistical significance: } \\
\hline Strains & & ns & $* *$ & $* *$ \\
\hline \multicolumn{5}{|l|}{ pH: } \\
\hline 4.0 & - & $170,667 \pm 59,121 \mathrm{~A}$ & $17,067 \pm 7390 \mathrm{~B}$ & $273,066 \pm 118,241 \mathrm{~A}$ \\
\hline 5.0 & - & $170,667 \pm 59,121 \mathrm{~A}$ & $25,600 \pm 0 B$ & $409,600 \pm 0 C$ \\
\hline 6.0 & - & $204,800 \pm 0 A$ & $25,600 \pm 0 \mathrm{~B}$ & $819,200 \pm 0 C$ \\
\hline 7.0 & - & $204,800 \pm 0 A$ & $21,333 \pm 7390 B$ & $819,200 \pm 0 C$ \\
\hline 8.0 & - & $204,800 \pm 0 A$ & $25,600 \pm 0 B$ & $682,667 \pm 236,483 C$ \\
\hline 9.0 & - & $204,800 \pm 0 A$ & $25,600 \pm 0 B$ & $409,600 \pm 0 C$ \\
\hline \multicolumn{5}{|c|}{ Statistical significance: } \\
\hline Strains & & ns & ns & $*$ \\
\hline
\end{tabular}

The results are expressed in activity units $(\mathrm{AU}) / \mathrm{mL}$ and indicate mean value $\pm \mathrm{SD}$ of three replicates. The activity was measured in MRS supernatants.

- , no inhibition.

All assays were carried out against $L$. monocytogenes ATCC 19114

$P$ value: ${ }^{*}, P \leq 0.05 ;{ }^{* *}, P \leq 0.01 ;$ ns $=$ not significant.

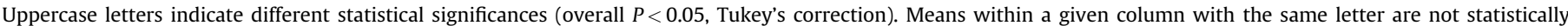
different from each other.

a Growth in MRS at $30^{\circ} \mathrm{C}$ for $24 \mathrm{~h}$.

\subsection{Effect of different incubation temperatures and initial growth pHs on bacteriocin activity}

Growth at temperatures different from $30^{\circ} \mathrm{C}$ (Table 3 ) did not affect $(P>0.05)$ bacteriocin production for the strain WFE3, but determined a consistent decrease $(P<0.05)$ for the activities of supernatants from the strains WFE20 and WFE31. The effect of $\mathrm{pH}$ of the MRS medium different from 6.5 on the bacteriocin production was significant $(P<0.05)$ only for the strain WFE31, bacteriocin WFE20 at pH 4.0 and for WFE31 at pH 4.0 and 5.0.

\subsection{Evaluation of cytotoxicity and antibiotic sensitivity}

Hemolysis of human erythrocytes was negative in PBS and Enterococcus supernatants, showing that the metabolites of the tested strains were not hemolytic.
For the evaluation of the effect of the antibiotics, using CLSI breakpoints for enterococci, all Enterococcus strains resulted resistant to penicillin and susceptible to ampicillin, quinupristin-dalfopristin, linezolid and vancomycin (results not shown).

\subsection{Analysis of bacteriocin determinants}

In order to analyze the DNA sequences encoding for bacteriocins, two different PCR amplifications were performed with DNAs extracted from Enterococcus strains. By means of the primer pairs Mnt-1F/and Mnt-1R, a $380 \mathrm{bp}-$ long fragment was amplified from WFE3, WFE20 and WFE31 genomic DNA (Fig. 3A), while only WFE3 and WFE31 strains showed a PCR product of approximately $3128 \mathrm{bp}$ with Mun1R/Mun7R (Fig. 3B). No amplification product was obtained from the DNA of the non bacteriocin producer $E$. mundtii PON10063.
A

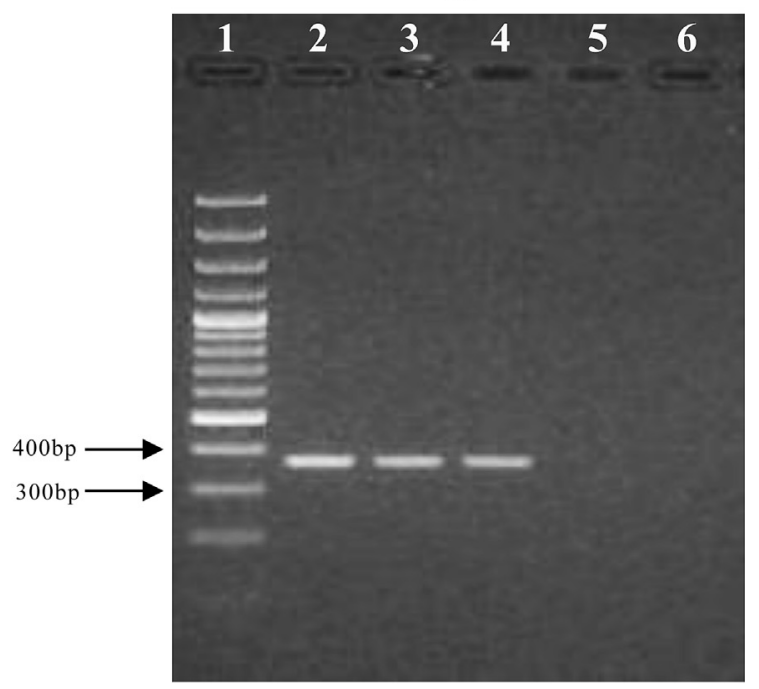

B

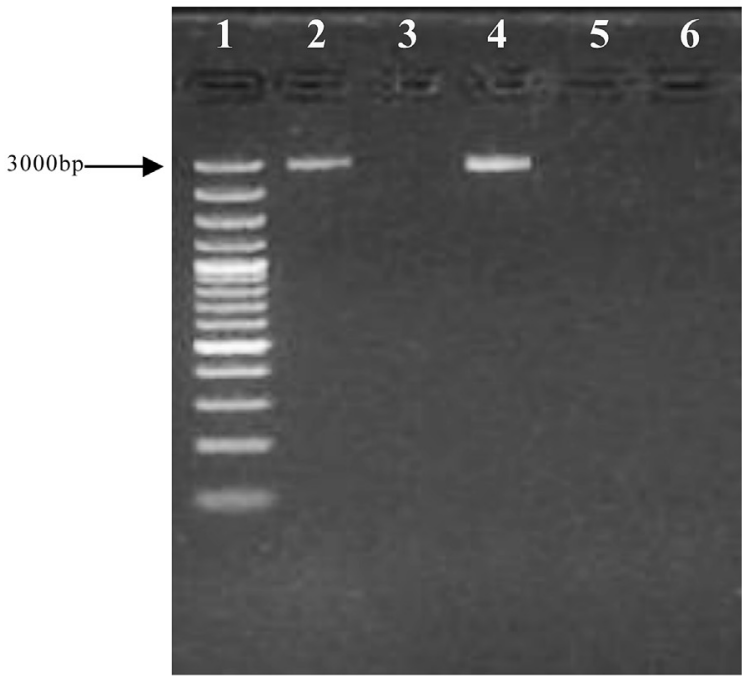

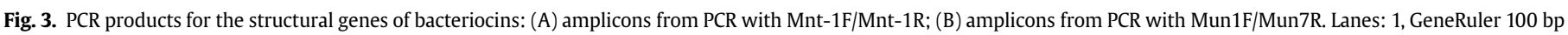
Plus DNA ladder (M-Medical); 2, E. mundtii WFE3; 3, E. mundtii WFE20; 4, E. mundtii WFE31; 5, E. mundtii PON10063; 6, PCR negative control. 
The sequences of the $380 \mathrm{bp}$ amplicons (Fig. 4) revealed that all three Enterococcus strains active against $L$. monocytogenes ATCC 19114 possessed bacteriocin-coding genes sharing 99\% identity with mundticin KS (Kawamoto et al., 2002). Moreover, a complete open reading frame (ORF) was deduced from the structural gene of the three bacteriocins. It was found to encode the bacteriocin precursor (58 amino acid residues). Mature predicted peptides showed $100 \%$ identity to mundticin KS. Additionally, high sequence similarity was observed comparing aminoacidic sequences from strains WFE3, WFE20 and WFE31 to different bacteriocins in the mundticin group of class Ila, such as mundticin L (98\%) and enterocin CRL35 (98\%). A second partial ORF was also predicted from all three bacteriocin producing strains and it was found to encode for a putative ATP binding cassette $(\mathrm{ABC})$ transporter.

\subsection{Bacteriocin production in food model systems}

Bacteriocin production in the different autoclaved and filtered food broths is reported in Table 4 . A very low residual activity $(0.01-4.17 \%)$ was recovered from the autoclaved food model systems after the growth of bacteriocin producing $E$. mundtii strains, while the filtration of the food models allowed a general higher retention of inhibitory activities for all strains which reached $33.07 \%$ for the strain WFE20 in MB. However, no activity was recovered from filtered $\mathrm{ChB}$ inoculated with the strains WFE20 and WFE31. Except autoclaved $\mathrm{CeB}$ and filtered $\mathrm{ChB}$, the best results in terms of activity recovery were shown by the strain WFE20. On the contrary, the strongest reduction of the anti-Listeria inhibition was registered for the strain WFE31 in all food model systems sterilized both by autoclaving and filtration. The two methodology applied for the sterilization of the model systems did not determine significant differences $(P>0.05)$ of $\mathrm{pH}$ and $a_{w}$, but the food models were statistically different $(P<0.001)$.

\subsection{In situ anti-listerial activity of bacteriocin producing E. mundtii strains}

The effects of the active strains against $L$. monocytogenes ATCC 19114 during growth in the different autoclaved and filtered food model systems are shown in Table 5. Tests performed in MRS

A
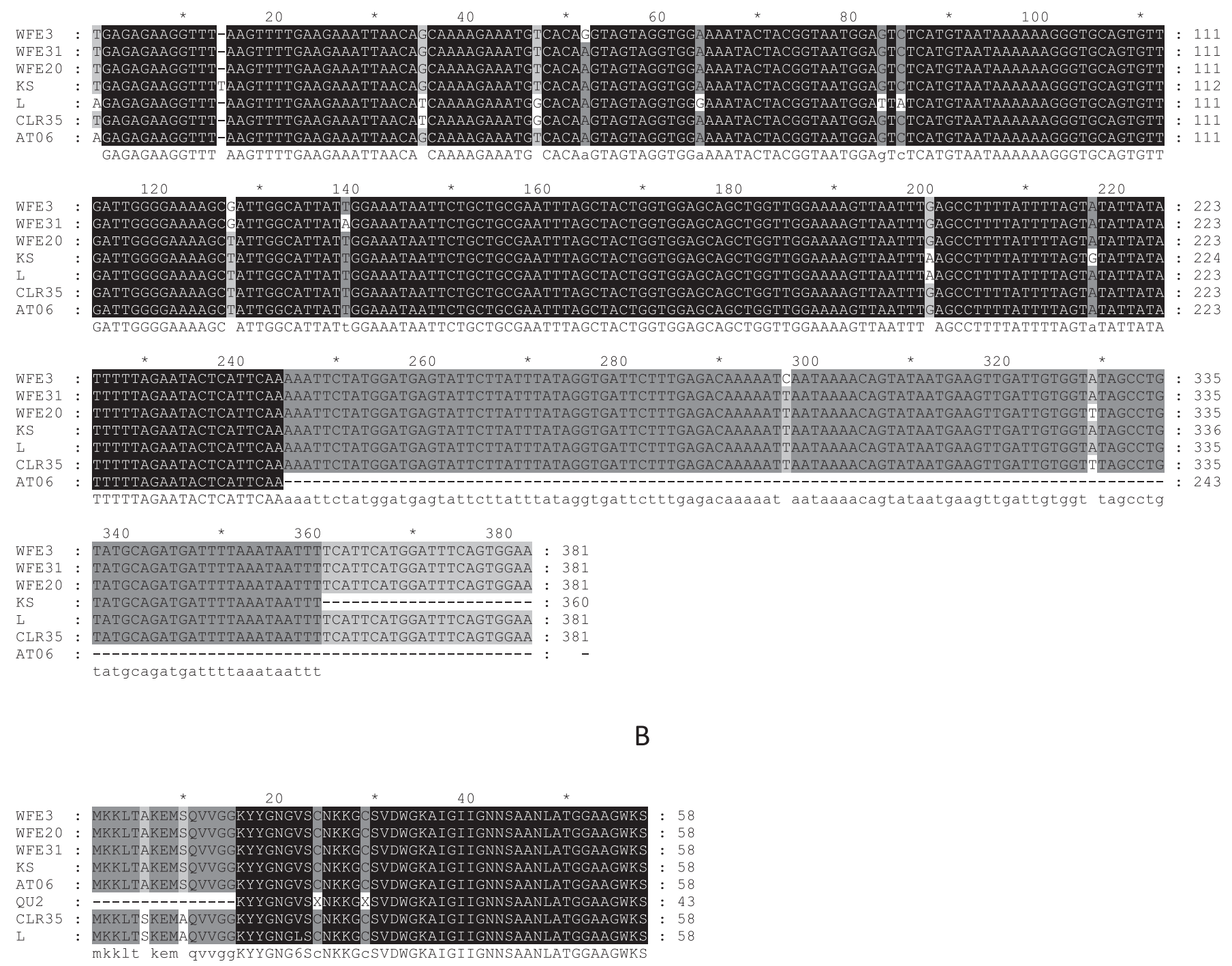

Fig. 4. Alignment of the structural bacteriocin-coding genes (A) and aminoacidic sequences; (B) in E. mundtii WFE3, WFE20 and WFE31. 
Table 4

Bacteriocin production ${ }^{\mathrm{a}}$ by E. mundtii WFE3, WFE20, and WFE31 in food model systems.

\begin{tabular}{|c|c|c|c|c|c|c|}
\hline \multirow[t]{2}{*}{ Food model systems } & \multicolumn{2}{|c|}{$\begin{array}{l}\text { Characteristics of food } \\
\text { models }^{b}\end{array}$} & \multicolumn{4}{|c|}{ Enterococcus strains } \\
\hline & $\mathrm{pH}$ & $a_{w}$ & PON10063 & WFE3 (residual activity \%) & WFE20 (residual activity \%) & WFE31 (residual activity \%) \\
\hline Autoclaved CeB & $6.10 \pm 0.02$ & $0.957 \pm 0.001$ & - & $4267 \pm 1867(1.56) \mathrm{A}$ & $533 \pm 231(1.04) \mathrm{B}$ & $200 \pm 0(0.02) \mathrm{B}$ \\
\hline Filtered CeB & $6.37 \pm 0.02$ & $0.933 \pm 0.001$ & - & $4266 \pm 1847(1.56) \mathrm{A}$ & $800 \pm 0(1.56) \mathrm{B}$ & $8533 \pm 3695(1.04) A$ \\
\hline Autoclaved ChB & $5.12 \pm 0.01$ & $0.960 \pm 0.001$ & - & $1600 \pm 0(0.59) \mathrm{A}$ & $2133 \pm 924$ (4.17)A & $533 \pm 231(0.06) B$ \\
\hline Filtered ChB & $5.60 \pm 0.02$ & $0.918 \pm 0.001$ & - & $50 \pm 0(0.02) \mathrm{A}$ & $0(0) \mathrm{B}$ & $0(0) \mathrm{B}$ \\
\hline Autoclaved FB & $6.62 \pm 0.03$ & $0.946 \pm 0.001$ & - & $50 \pm 0(0.02) \mathrm{A}$ & $200 \pm 0(0.39) B$ & $50 \pm 0(0.01) A$ \\
\hline Filtered FB & $6.61 \pm 0.01$ & $0.980 \pm 0.001$ & - & $12,800 \pm 0(4.69) \mathrm{A}$ & $8533 \pm 3695$ (16.67)AC & $4266 \pm 1847(0.52) \mathrm{BC}$ \\
\hline Autoclaved MB & $6.42 \pm 0.01$ & $0.958 \pm 0.001$ & - & $1067 \pm 462(0.39) \mathrm{A}$ & $400 \pm 0(0.78) A$ & $50 \pm 0(0.01) \mathrm{B}$ \\
\hline Filtered MB & $5.86 \pm 0.03$ & $0.903 \pm 0.001$ & - & $12,800 \pm 0(4.69) \mathrm{A}$ & $16,933 \pm 7159(33.07) A$ & $8533 \pm 3695(1.04) A$ \\
\hline Autoclaved VB & $5.33 \pm 0.03$ & $0.953 \pm 0.001$ & - & $100 \pm 0(0.04) \mathrm{A}$ & $533 \pm 231(1.04) \mathrm{B}$ & $400 \pm 0(0.04) \mathrm{B}$ \\
\hline Filtered VB & $5.05 \pm 0.02$ & $0.929 \pm 0.001$ & - & $2133 \pm 924(0.78) \mathrm{A}$ & $1600 \pm 0(3.13) \mathrm{AB}$ & $800 \pm 0(0.10) A C$ \\
\hline \multicolumn{7}{|l|}{ Statistical significance: } \\
\hline Treatment $(T)$ & ns & ns & ns & $*$ & $*$ & $* * *$ \\
\hline Broth $(B)$ & $* * *$ & $* * *$ & ns & ns & ns & ns \\
\hline$T^{*} B$ & ns & $* * *$ & ns & $* * *$ & $* * *$ & $* * *$ \\
\hline
\end{tabular}

- , no inhibition.

All assays were carried out against L. monocytogenes ATCC 19114.

Abbreviations: $\mathrm{CeB}$, cereal broth; $\mathrm{ChB}$, cheese broth; $\mathrm{FB}$, fish broth; $\mathrm{MB}$, meat broth; $\mathrm{VB}$, vegetable broth

$P$ value: ${ }^{*}, P \leq 0.05$; ${ }^{* *}, P \leq 0.001 ;$ ns $=$ not significant.

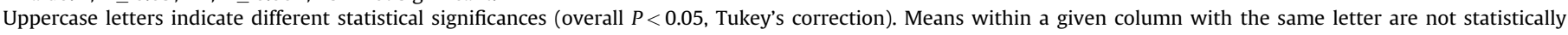
different from each other.

a The results are expressed in activity units $(\mathrm{AU}) / \mathrm{mL}$ and indicate mean value $\pm \mathrm{SD}$ of three replicates.

b Evaluated before inoculation.

confirmed the bactericidal effect of the three bacteriocinogenic strains against $L$. monocytogenes ATCC 19114. The growth of the indicator strain reached the maximal level generally at the second day of incubation, when a concentration of about $10^{7} \mathrm{CFU} / \mathrm{mL}$ was registered in MRS and in almost all food models except filtered ChB and filtered $\mathrm{MB}$ for which a decrease was recorded from the first day on. Thus, for these two food models the inhibition of L. monocytogenes ATCC 19114 may be mainly imputable to the low $a_{w}$ (below 0.92). All levels of concentration registered for the indicator strain in absence of E. mundtii were comparable $(P>0.05)$ to those showed in presence of the non bacteriocin producer E. mundtii PON10063. No differences $(P>0.05)$ were registered for the three bacteriocins among autoclaved and filtered MRS, filtered $\mathrm{CeB}$, filtered $\mathrm{ChB}$, autoclaved $\mathrm{FB}$, autoclaved $\mathrm{MB}$, autoclaved VB and filtered VB. The growth of $L$. monocytogenes ATCC 19114 was completely inhibited within the first $24 \mathrm{~h}$ of co-culturing in MRS, filtered $\mathrm{CeB}$, filtered $\mathrm{ChB}$ and autoclaved VB, while the highest Listeria survival was observed in autoclaved $\mathrm{MB}$ and in presence of all three E. mundtii strains.

\section{Discussion}

In the present work, the bacterial isolates WFE3, WFE20 and WFE31 of wheat flour origin, presumptively allotted into the group of enterococci on the basis of growth on a kanamycin containing agar medium and preliminarily screened as producers of antimicrobial compounds (work in preparation), were characterized for their potential application as bio-preservative agents.

The three isolates were identified by a multiple genotypic approach as three distinct E. mundtii strains. Their supernatants were tested against pro-technological, spoilage and pathogen bacteria. Several strains of LAB were used as indicators, since they are commonly used as starter cultures in food fermentations. A bacteriocin active against starter LAB may have detrimental effects and, for this reason, not applicable in fermented food systems. E. mundtii WFE3, WFE20 and WFE31 were all found to be particularly active against Listeria spp. Within this group, $L$. monocytogenes is a difficult pathogen to control because of its ubiquitous distribution, tolerance to high levels of salt and its stability to grow at a relatively low $\mathrm{pH}$ and at refrigeration temperatures (Guinane, Cotter, Hill, \& Ross, 2005). The anti-listerial effects of LAB are a wanted characteristic, since it strongly contributes to the safety of the final foods (Deegan, Cotter, Hill, \& Ross, 2006). The three strains behaved similarly and they inhibited only a few species within the pro-technological bacterial group, but they were ineffective against Gram-negative bacteria, at least in the non concentrated form. Our findings showed the common characteristics of bacteriocins, because they are active mostly on strains closely related to the producer strains (Cotter, Hill, \& Ross, 2005). The activity of some bacteriocins from LAB against Gram-negative bacteria is an unusual phenomenon; only a few bacteriocins possessed this behavior (Kuwano et al., 2005; Todorov \& Dicks, 2005).

Proteolytic enzymes determined the loss of inhibitory activity for all three supernatants, proving their proteinaceous nature, a general characteristic of bacteriocins (Jack, Tagg, \& Ray, 1995). Treatment with $\alpha$-amylase and lipase did not alter the antibacterial activity of the active supernatants, suggesting that the active compounds did not contain a sugar or lipid moiety. A resistance of the bacteriocins to the heat treatments was registered. According to the classification of Nes et al. (1996), the bacteriocins WFE3, WFE20 and WFE31 were considered members of class II.

The retention of inhibitory power of the E. mundtii active supernatants in the wide $\mathrm{pH}$ range considered and in presence of different percentages of ethanol provided evidences of their possible application in several food ecosystems. From this perspective, when a bacteriocinogenic strain is applied during fermentation it is also important to evaluate the production of bacteriocin in different conditions that may characterize the food environment during growth (Settanni et al., 2008).

Generally, bacteriocin production by LAB is reported as a temperature-sensitive process, whereby the optimal temperature for bacteriocin production does not necessarily coincide with the optimal growth temperature (Leroy \& De Vuyst, 1999). It has been suggested that bacteriocin production by LAB is enhanced by suboptimal temperatures (Delgado, Brito, Peres, Noé-Arroyo López, \& Garrido-Fernández, 2005). However, in the present study, as already observed in a previous study by Settanni et al. (2008), the results showed that temperatures different from those in the range 
Table 5

In situ anti-listerial activity ${ }^{\mathrm{a}}$ of bacteriocin producing Enterococcus strains.

\begin{tabular}{|c|c|c|c|c|c|c|}
\hline \multirow[t]{2}{*}{ Growth media } & \multirow[t]{2}{*}{ Time } & \multicolumn{5}{|c|}{ Growth of L. monocytogenes ATCC 19114 (Log CFU/mL) in co-culture with Enterococcus mundtii } \\
\hline & & Without Enterococcus strains & Strain PON10063 & Strain WFE3 & Strain WFE20 & Strain WFE31 \\
\hline Autoclaved MRS & $T_{0}$ & $4.65 \pm 0.40 \mathrm{~A}$ & $4.61 \pm 0.26 \mathrm{~A}$ & $4.75 \pm 0.26 \mathrm{~A}$ & $4.62 \pm 0.18 \mathrm{~A}$ & $4.66 \pm 0.36 \mathrm{~A}$ \\
\hline Autoclaved MRS & $1 \mathrm{~d}$ & $6.88 \pm 0.38 \mathrm{~A}$ & $6.30 \pm 0.32 \mathrm{~A}$ & $0.00 \pm 0.00 \mathrm{~B}$ & $0.00 \pm 0.00 \mathrm{~B}$ & $0.00 \pm 0.00 \mathrm{~B}$ \\
\hline Autoclaved MRS & $2 \mathrm{~d}$ & $7.70 \pm 0.30 \mathrm{~A}$ & $6.70 \pm 0.28 \mathrm{~A}$ & $0.00 \pm 0.00 \mathrm{~B}$ & $0.00 \pm 0.00 \mathrm{~B}$ & $0.00 \pm 0.00 \mathrm{~B}$ \\
\hline Autoclaved MRS & $5 \mathrm{~d}$ & $6.10 \pm 0.25 \mathrm{~A}$ & $5.70 \pm 0.29 \mathrm{~A}$ & $0.00 \pm 0.00 \mathrm{~B}$ & $0.00 \pm 0.00 \mathrm{~B}$ & $0.00 \pm 0.00 \mathrm{~B}$ \\
\hline Filtered MRS & $T_{0}$ & $4.70 \pm 0.30 \mathrm{~A}$ & $4.52 \pm 0.30 \mathrm{~A}$ & $4.81 \pm 0.40 \mathrm{~A}$ & $5.00 \pm 0.30 \mathrm{~A}$ & $4.56 \pm 0.40 \mathrm{~A}$ \\
\hline Filtered MRS & $1 \mathrm{~d}$ & $6.71 \pm 0.30 \mathrm{~A}$ & $6.70 \pm 0.40 \mathrm{~A}$ & $0.00 \pm 0.00 \mathrm{~B}$ & $0.00 \pm 0.00 \mathrm{~B}$ & $0.00 \pm 0.00 \mathrm{~B}$ \\
\hline Filtered MRS & $2 \mathrm{~d}$ & $7.76 \pm 0.32 \mathrm{~A}$ & $7.52 \pm 0.36 \mathrm{~A}$ & $0.00 \pm 0.00 \mathrm{~B}$ & $0.00 \pm 0.00 \mathrm{~B}$ & $0.00 \pm 0.00 \mathrm{~B}$ \\
\hline Filtered MRS & $5 \mathrm{~d}$ & $5.23 \pm 0.13 \mathrm{~A}$ & $5.60 \pm 0.41 \mathrm{~A}$ & $0.00 \pm 0.00 \mathrm{~B}$ & $0.00 \pm 0.00 \mathrm{~B}$ & $0.00 \pm 0.00 \mathrm{~B}$ \\
\hline Autoclaved $\mathrm{CeB}$ & $T_{0}$ & $4.60 \pm 0.30 \mathrm{~A}$ & $4.75 \pm 0.34 \mathrm{~A}$ & $4.66 \pm 0.34 \mathrm{~A}$ & $4.77 \pm 0.24 \mathrm{~A}$ & $4.75 \pm 0.34 \mathrm{~A}$ \\
\hline Autoclaved $\mathrm{CeB}$ & $1 \mathrm{~d}$ & $6.84 \pm 0.40 \mathrm{~A}$ & $6.81 \pm 0.52 \mathrm{~A}$ & $0.00 \pm 0.00 \mathrm{~B}$ & $0.00 \pm 0.00 \mathrm{~B}$ & $2.00 \pm 0.40 \mathrm{C}$ \\
\hline Autoclaved $\mathrm{CeB}$ & $2 \mathrm{~d}$ & $6.60 \pm 0.34 \mathrm{~A}$ & $6.65 \pm 0.52 \mathrm{~A}$ & $0.00 \pm 0.00 \mathrm{~B}$ & $0.00 \pm 0.00 \mathrm{~B}$ & $1.70 \pm 0.30 \mathrm{C}$ \\
\hline Autoclaved $\mathrm{CeB}$ & $5 \mathrm{~d}$ & $5.40 \pm 0.27 \mathrm{~A}$ & $5.65 \pm 0.50 \mathrm{~A}$ & $0.00 \pm 0.00 \mathrm{~B}$ & $0.00 \pm 0.00 \mathrm{~B}$ & $0.70 \pm 0.30 \mathrm{~B}$ \\
\hline Filtered CeB & $T_{0}$ & $4.54 \pm 0.25 \mathrm{~A}$ & $4.68 \pm 0.39 A$ & $4.58 \pm 0.18 \mathrm{~A}$ & $4.95 \pm 0.41 \mathrm{~A}$ & $4.54 \pm 0.26 \mathrm{~A}$ \\
\hline Filtered CeB & $1 \mathrm{~d}$ & $6.45 \pm 0.32 \mathrm{~A}$ & $6.91 \pm 0.52 \mathrm{~A}$ & $0.00 \pm 0.00 \mathrm{~B}$ & $0.00 \pm 0.00 \mathrm{~B}$ & $0.00 \pm 0.00 \mathrm{~B}$ \\
\hline Filtered CeB & $2 \mathrm{~d}$ & $6.20 \pm 0.36 \mathrm{~A}$ & $6.55 \pm 0.54 \mathrm{~A}$ & $0.00 \pm 0.00 \mathrm{~B}$ & $0.00 \pm 0.00 \mathrm{~B}$ & $0.00 \pm 0.00 \mathrm{~B}$ \\
\hline Filtered CeB & $5 \mathrm{~d}$ & $5.29 \pm 0.22 \mathrm{~A}$ & $5.36 \pm 0.50 \mathrm{~A}$ & $0.00 \pm 0.00 \mathrm{~B}$ & $0.00 \pm 0.00 \mathrm{~B}$ & $0.00 \pm 0.00 \mathrm{~B}$ \\
\hline Autoclaved ChB & $T_{0}$ & $4.61 \pm 0.39 \mathrm{~A}$ & $4.77 \pm 0.39 \mathrm{~A}$ & $4.72 \pm 0.31 \mathrm{~A}$ & $4.75 \pm 0.21 \mathrm{~A}$ & $4.72 \pm 0.31 \mathrm{~A}$ \\
\hline Autoclaved ChB & $1 \mathrm{~d}$ & $6.27 \pm 0.29 \mathrm{~A}$ & $6.58 \pm 0.25 A$ & $2.18 \pm 0.29 \mathrm{~B}$ & $2.48 \pm 0.39 \mathrm{~B}$ & $2.40 \pm 0.39 \mathrm{~B}$ \\
\hline Autoclaved ChB & $2 \mathrm{~d}$ & $7.09 \pm 0.36 \mathrm{~A}$ & $7.26 \pm 0.26 \mathrm{~A}$ & $0.00 \pm 0.00 \mathrm{~B}$ & $0.00 \pm 0.00 \mathrm{~B}$ & $2.70 \pm 0.20 \mathrm{C}$ \\
\hline Autoclaved ChB & $5 \mathrm{~d}$ & $6.21 \pm 0.34 \mathrm{~A}$ & $6.26 \pm 0.33 \mathrm{~A}$ & $0.00 \pm 0.00 \mathrm{~B}$ & $0.00 \pm 0.00 \mathrm{~B}$ & $1.70 \pm 0.20 \mathrm{C}$ \\
\hline Filtered ChB & $T_{0}$ & $4.82 \pm 0.39 \mathrm{~A}$ & $4.71 \pm 0.30 \mathrm{~A}$ & $4.52 \pm 0.31 \mathrm{~A}$ & $4.35 \pm 0.21 \mathrm{~A}$ & $4.75 \pm 0.31 \mathrm{~A}$ \\
\hline Filtered ChB & $1 \mathrm{~d}$ & $3.81 \pm 0.30 \mathrm{~A}$ & $3.90 \pm 0.17 \mathrm{~A}$ & $0.00 \pm 0.00 \mathrm{~B}$ & $0.00 \pm 0.00 \mathrm{~B}$ & $0.00 \pm 0.00 \mathrm{~B}$ \\
\hline Filtered ChB & $2 \mathrm{~d}$ & $3.78 \pm 0.26 \mathrm{~A}$ & $3.88 \pm 0.22 \mathrm{~A}$ & $0.00 \pm 0.00 \mathrm{~B}$ & $0.00 \pm 0.00 \mathrm{~B}$ & $0.00 \pm 0.00 \mathrm{~B}$ \\
\hline Filtered ChB & $5 \mathrm{~d}$ & $3.85 \pm 0.30 \mathrm{~A}$ & $3.95 \pm 0.35 \mathrm{~A}$ & $0.00 \pm 0.00 \mathrm{~B}$ & $0.00 \pm 0.00 \mathrm{~B}$ & $0.00 \pm 0.00 \mathrm{~B}$ \\
\hline Autoclaved FB & $T_{0}$ & $4.50 \pm 0.29 \mathrm{~A}$ & $4.70 \pm 0.44 \mathrm{~A}$ & $4.70 \pm 0.24 \mathrm{~A}$ & $4.65 \pm 0.44 \mathrm{~A}$ & $4.62 \pm 0.24 \mathrm{~A}$ \\
\hline Autoclaved FB & $1 \mathrm{~d}$ & $7.03 \pm 0.25 \mathrm{~A}$ & $6.49 \pm 0.45 \mathrm{~A}$ & $2.70 \pm 0.15 \mathrm{~B}$ & $2.70 \pm 0.35 \mathrm{~B}$ & $3.00 \pm 0.25 \mathrm{~B}$ \\
\hline Autoclaved FB & $2 \mathrm{~d}$ & $7.70 \pm 0.38 \mathrm{~A}$ & $7.95 \pm 0.35 \mathrm{~A}$ & $0.00 \pm 0.00 \mathrm{~B}$ & $0.00 \pm 0.00 \mathrm{~B}$ & $0.00 \pm 0.00 \mathrm{~B}$ \\
\hline Autoclaved FB & $5 \mathrm{~d}$ & $6.82 \pm 0.30 \mathrm{~A}$ & $6.95 \pm 0.44 \mathrm{~A}$ & $0.00 \pm 0.00 \mathrm{~B}$ & $0.00 \pm 0.00 \mathrm{~B}$ & $0.00 \pm 0.00 \mathrm{~B}$ \\
\hline Filtered FB & $T_{0}$ & $4.64 \pm 0.20 \mathrm{~A}$ & $4.68 \pm 0.29 \mathrm{~A}$ & $4.76 \pm 0.45 \mathrm{~A}$ & $4.59 \pm 0.33 \mathrm{~A}$ & $4.69 \pm 0.36 \mathrm{~A}$ \\
\hline Filtered FB & $1 \mathrm{~d}$ & $6.60 \pm 0.34 \mathrm{~A}$ & $6.48 \pm 0.48 \mathrm{~A}$ & $2.70 \pm 0.32 \mathrm{~B}$ & $0.00 \pm 0.00 \mathrm{C}$ & $0.00 \pm 0.00 \mathrm{C}$ \\
\hline Filtered FB & $2 \mathrm{~d}$ & $7.18 \pm 0.40 A$ & $7.27 \pm 0.27 \mathrm{~A}$ & $2.08 \pm 0.30 \mathrm{~B}$ & $0.00 \pm 0.00 C$ & $0.00 \pm 0.00 \mathrm{C}$ \\
\hline Filtered FB & $5 \mathrm{~d}$ & $6.65 \pm 0.35 \mathrm{~A}$ & $6.90 \pm 0.35 \mathrm{~A}$ & $2.00 \pm 0.36 \mathrm{~B}$ & $0.00 \pm 0.00 \mathrm{C}$ & $0.00 \pm 0.00 \mathrm{C}$ \\
\hline Autoclaved MB & $T_{0}$ & $4.30 \pm 0.25 \mathrm{~A}$ & $4.62 \pm 0.24 \mathrm{~A}$ & $4.68 \pm 0.14 \mathrm{~A}$ & $4.65 \pm 0.34 \mathrm{~A}$ & $4.76 \pm 0.44 \mathrm{~A}$ \\
\hline Autoclaved MB & $1 \mathrm{~d}$ & $6.88 \pm 0.32 \mathrm{~A}$ & $6.86 \pm 0.20 \mathrm{~A}$ & $2.40 \pm 0.20 \mathrm{~B}$ & $2.00 \pm 0.20 \mathrm{~B}$ & $2.18 \pm 0.20 \mathrm{~B}$ \\
\hline Autoclaved MB & $2 \mathrm{~d}$ & $6.70 \pm 0.31 \mathrm{~A}$ & $7.11 \pm 0.42 \mathrm{~A}$ & $2.40 \pm 0.12 B$ & $2.00 \pm 0.52 B$ & $2.53 \pm 0.42 B$ \\
\hline Autoclaved MB & $5 \mathrm{~d}$ & $5.94 \pm 0.26 \mathrm{~A}$ & $6.11 \pm 0.34 \mathrm{~A}$ & $1.40 \pm 0.21 \mathrm{~B}$ & $1.00 \pm 0.42 B$ & $1.53 \pm 0.21 \mathrm{~B}$ \\
\hline Filtered MB & $T_{0}$ & $4.68 \pm 0.30 \mathrm{~A}$ & $4.58 \pm 0.25 \mathrm{~A}$ & $4.53 \pm 0.27 \mathrm{~A}$ & $4.69 \pm 0.29 A$ & $4.81 \pm 0.26 \mathrm{~A}$ \\
\hline Filtered MB & $1 \mathrm{~d}$ & $3.59 \pm 0.30 \mathrm{~A}$ & $3.70 \pm 0.30 \mathrm{~A}$ & $0.00 \pm 0.00 \mathrm{~B}$ & $0.70 \pm 0.40 \mathrm{~B}$ & $0.00 \pm 0.00 \mathrm{~B}$ \\
\hline Filtered MB & $2 \mathrm{~d}$ & $3.58 \pm 0.26 \mathrm{~A}$ & $3.28 \pm 0.26 \mathrm{~A}$ & $0.00 \pm 0.00 \mathrm{~B}$ & $0.00 \pm 0.00 \mathrm{~B}$ & $0.00 \pm 0.00 \mathrm{~B}$ \\
\hline Filtered MB & $5 \mathrm{~d}$ & $3.55 \pm 0.30 \mathrm{~A}$ & $3.85 \pm 0.30 \mathrm{~A}$ & $0.00 \pm 0.00 \mathrm{~B}$ & $0.00 \pm 0.00 \mathrm{~B}$ & $0.00 \pm 0.00 \mathrm{~B}$ \\
\hline Autoclaved VB & $T_{0}$ & $4.80 \pm 0.40 \mathrm{~A}$ & $4.70 \pm 0.25 \mathrm{~A}$ & $4.70 \pm 0.23 \mathrm{~A}$ & $4.72 \pm 0.33 \mathrm{~A}$ & $4.59 \pm 0.23 \mathrm{~A}$ \\
\hline Autoclaved VB & $1 \mathrm{~d}$ & $6.48 \pm 0.28 \mathrm{~A}$ & $6.18 \pm 0.36 \mathrm{~A}$ & $0.00 \pm 0.00 \mathrm{~B}$ & $0.00 \pm 0.00 \mathrm{~B}$ & $0.00 \pm 0.00 \mathrm{~B}$ \\
\hline Autoclaved VB & $2 \mathrm{~d}$ & $6.15 \pm 0.25 \mathrm{~A}$ & $6.30 \pm 0.23 \mathrm{~A}$ & $0.00 \pm 0.00 \mathrm{~B}$ & $0.00 \pm 0.00 \mathrm{~B}$ & $0.00 \pm 0.00 \mathrm{~B}$ \\
\hline Autoclaved VB & $5 \mathrm{~d}$ & $5.00 \pm 0.22 \mathrm{~A}$ & $5.30 \pm 0.21 \mathrm{~A}$ & $0.00 \pm 0.00 \mathrm{~B}$ & $0.00 \pm 0.00 \mathrm{~B}$ & $0.00 \pm 0.00 \mathrm{~B}$ \\
\hline Filtered VB & $T_{0}$ & $4.60 \pm 0.40 \mathrm{~A}$ & $4.80 \pm 0.25 \mathrm{~A}$ & $4.70 \pm 0.35 \mathrm{~A}$ & $4.67 \pm 0.25 \mathrm{~A}$ & $4.78 \pm 0.26 \mathrm{~A}$ \\
\hline Filtered VB & $1 \mathrm{~d}$ & $6.88 \pm 0.28 \mathrm{~A}$ & $6.68 \pm 0.36 \mathrm{~A}$ & $1.00 \pm 0.21 \mathrm{~B}$ & $1.00 \pm 0.29 \mathrm{~B}$ & $2.18 \pm 0.30 \mathrm{~B}$ \\
\hline Filtered VB & $2 \mathrm{~d}$ & $6.25 \pm 0.33 \mathrm{~A}$ & $6.40 \pm 0.23 \mathrm{~A}$ & $0.00 \pm 0.00 \mathrm{~B}$ & $0.00 \pm 0.00 \mathrm{~B}$ & $0.70 \pm 0.40 \mathrm{~B}$ \\
\hline Filtered VB & $5 \mathrm{~d}$ & $5.30 \pm 0.45 \mathrm{~A}$ & $5.33 \pm 0.21 \mathrm{~A}$ & $0.00 \pm 0.00 \mathrm{~B}$ & $0.00 \pm 0.00 \mathrm{~B}$ & $0.00 \pm 0.00 \mathrm{~B}$ \\
\hline
\end{tabular}

Results indicate mean value \pm SD of two replicates.

-, no growth.

Abbreviations: $\mathrm{CeB}$, cereal broth; $\mathrm{ChB}$, cheese broth; FB, fish broth; MB, meat broth; VB, vegetable broth.

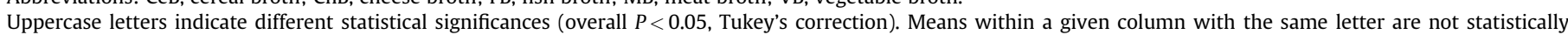
different from each other.

a Evaluated against L. monocytogenes ATCC 19114.

$\left(30-37^{\circ} \mathrm{C}\right.$ ) optimal for the growth of $E$. mundtii determined a lower production of the inhibitory compounds. Also the effect of the initial $\mathrm{pH}$ of the growth medium was in agreement with the previous findings (Settanni et al., 2008), showing a higher bacteriocin activity in the range 6.0-8.0. The neutral $\mathrm{pH}$ range is known to be optimal for bacteriocin production by enterococci (Leroy \& De Vuyst, 2002; Van den Berghe, De Winter, \& De Vuyst, 2006).

Although E. mundtii has not been reported as the cause of human outbreaks, as being a member of the group of enterococci its use in food applications needs to be validated by the absence of risks for consumer: e.g. absence of cytotoxicity and sensitivity to antibiotics. Hemolysis of human erythrocytes by the active supernatants was negative, proving that the whole metabolic production of E. mundtii WFE3, WFE20 and WFE31, including the bacteriocins, was not dangerous for the consumers' health. Our strains were sensitive to the antibiotics suggested by the CLSI, except to penicillin to which they resulted resistant. The resistance to penicillin is common to many enterococci (Murray, 1990), thus, the strains E. mundtii WFE3, WFE20, and WFE31 may be considered suitable for food application.

The three bacteriocins were genetically investigated. The structural genes were analyzed using primers mapping on the nucleotide sequence of $E$. mundtii bacteriocin-coding genes. All three strains were positive for the presence of a fragment of the known mundticin KS (Kawamoto et al., 2002), CRL35 (Saavedra et al., 2004), QU2 (Zendo et al., 2005) and MunL (Feng et al., 
2009), while only E. mundtii WFE20 was negative when analyzed with the primers designed for the biosynthetic cluster for enterocin CRL35. The nucleotide sequences of the three $381 \mathrm{bp}$ DNA fragments obtained after the first PCR amplification showed only five nucleotides different among the three strains. Furthermore, the aminoacidic sequences did not show any difference among the bacteriocins produced by E. mundtii WFE3, WFE20, and WFE31 and they were identical to mundticin KS (Kawamoto et al., 2002). The absence of amplification product from WFE20 total DNA with the primer pairs Mun1F/Mun7R could be due to the sequence polymorphisms among the three E. mundtii strains. This result reflects also the genetic differences highlighted by RAPD analysis.

Mundticin KS belongs to the class IIa (Kawamoto et al., 2002) which contains a consensus YGNGV amino acid motif near the $\mathrm{N}$ terminus. These bacteriocins are active against $L$. monocytogenes (Ennahar, Sashihara, Sonomoto, \& Ishizaki, 2000), a characteristic that determines their importance in industrial applications. Further analyses are necessary to characterize the entire bacteriocin genetic loci of E. mundtii WFE3, WFE20, and WFE31. Some mundticins have been reported to be encoded by gene clusters carried by plasmids (Feng et al., 2009; Kawamoto et al., 2002), but some E. mundtii strains have been found to express bacteriocins by chromosomal genes (Settanni et al., 2008). A character residing on chromosomal DNA is more stable than plasmid encoded information and may be significant for future applications of these strains at industrial level.

The influence of food components on bacteriocin production and activity was evaluated in five different food model systems obtained with fresh vegetables, cereals, cheeses, meats and fishes and subjected to two different sterilization procedures: autoclaving and filtration. Bacteriocin activity was recovered from almost all broths except filtered cheese broth inoculated with the strains WFE20 and WFE31. The production was strain dependent, but the best results were registered in filtered meat and fish broths. The different production may be imputable to the different presence and concentration of the food components, as well as to the different $\mathrm{pH}$ and $a_{w}$ of the food models. Type and concentration of carbon and nitrogen sources are relevant for bacteriocin production (Delgado et al., 2007). Several authors reported that higher bacteriocin activities are observed with increased nitrogen concentrations (Aasen et al., 2000; Kim et al., 1997).

Although with some differences, nine of the ten food model systems allowed bacteriocin production. Hence, all broths were used to test the in situ efficacy of the E. mundtii strains against L. monocytogenes during the simulation of a common fermentation. The inhibition produced by the growing cultures was often good. This because, in addition to the bacteriocin production, the competition for nutrients, initial $\mathrm{pH}$ and $a_{w}$ might have been limiting for the development of $L$. monocytogenes. In particular, filtered ChB and filtered MB were characterized by $a_{w}$ below 0.92 , which is reported to be the limit for the growth of $L$. monocytogenes in presence of $\mathrm{NaCl}$ and sucrose (Nolan, Chamblin, \& Troller, 1992). Some $E$. mundtii have already been found effective in situ against L. monocytogenes in vegetable, cheese and fish products (Bennik et al., 1999; Bigwood et al., 2012; Vera Pingitore et al., 2012), but their bacteriocins have not been characterized for nucleotide or amino acid sequences.

This work was mainly performed to evaluate the effect of several foods (different in composition and nutrient concentrations) on the expression and activity of bacteriocins produced by three $E$. mundtii strains. The results showed that all three strains were able to produce the antimicrobial compounds in different food matrices and to control the growth of $L$. monocytogenes in situ during the fermentation process. Works will be prepared to follow the bacteriocin expression in the different food matrices.

\section{Acknowledgments}

This work was financially supported by the project for industrial research and training PON01_02249 “Application of molecular biotechnologies and pro-technological microorganisms for the characterization and valorization of dairy and bakery chains of typical products" of the Italian Ministry of Education, University and Research (CUP: B11C11000430005). Prof. Baldassare Portolano (University of Palermo) is thanked for his involvement in the realization of the project and Dr. Aldo Todaro (university of Palermo) for aw analysis.

\section{References}

Aasen, I. M., Moretro, T., Katla, T., Axelsson, L., \& Storro, I. (2000). Influence of complex nutrients, temperature and $\mathrm{pH}$ on bacteriocin production by Lactobacillus sakei CCUG 42687. Applied Microbiology and Biotechnology, 53, 159-166.

Aasen, I. M., Markussen, S., Moretro, T., Katla, T., Axelsson, L., \& Naterstad, K. (2003). Interactions of the bacteriocins sakacin $\mathrm{P}$ and nisin with food constituents. International Journal of Food Microbiology, 87, 35-43.

Barefoot, S. F., \& Klaenhammer, T. R. (1983). Detection and activity of lactacin B, a bacteriocin produced by Lactobacillus acidophilus. Applied and Environmental Microbiology, 45, 1808-1815.

Bennik, M. H., van Overbeek, W., Smid, E. J., \& Gorris, L. G. (1999). Biopreservation in modified atmosphere stored mungbean sprouts: the use of vegetableassociated bacteriocinogenic lactic acid bacteria to control the growth of Listeria monocytogenes. Letters in Applied Microbiology, 28, 226-232.

Bigwood, T., Hudson, J. A., Cooney, J., McIntyre, L., Billington, C., Heinemann, J. A., et al. (2012). Inhibition of Listeria monocytogenes by Enterococcus mundtii isolated from soil. Food Microbiology, 32, 354-360.

Clinical and Laboratory Standards Institute. (2011). Performance standards for antimicrobial susceptibility testing; twenty-first informational supplement. CLSI document M100-S21. Wayne, PA: Clinical and Laboratory Standards Institute.

Corsetti, A., Settanni, L., Braga, T., Lopes, M., \& Suzzi, G. (2008). An investigation of the bacteriocinogenic potential of lactic acid bacteria associated with wheat (Triticum durum) kernels and non-conventional flours. Lwt-Food Science and Technology, 41, 1173-1182.

Corsetti, A., Settanni, L., Chaves López, C., Felis, G. E., Mastrangelo, M., \& Suzzi, G. (2007). A taxonomic survey of lactic acid bacteria isolated from wheat (Triticum durum) kernels and non-conventional flours. Systematic and Applied Microbiology, 30, 561-571.

Corsetti, A., Settanni, L., \& Van Sinderen, D. (2004). Characterization of bacteriocinlike inhibitory substances (BLIS) from sourdough lactic acid bacteria and evaluation of their in vitro and in situ activity. Journal of Applied Microbiology, 96, 521-534.

Cotter, P., Hill, C., \& Ross, R. (2005). Bacteriocins: developing innate immunity for food. Nature Reviews Microbiology, 3, 777-788.

Deegan, L., Cotter, P., Hill, C., \& Ross, P. (2006). Bacteriocins: biological tools for biopreservation and shelf-life extension. International Dairy Journal, 16, 1058-1071.

Delgado, A., Brito, D., Peres, C., Noé-Arroyo López, F., \& Garrido-Fernández, A (2005). Bacteriocin production by Lactobacillus pentosus B96 can be expressed as a function of temperature and $\mathrm{NaCl}$ concentration. Food Microbiology, 22, 521-528.

Delgado, A., Noé-Arroyo López, F., Brito, D., Peres, C., Fevereiro, P., \& GarridoFernández, A. (2007). Optimum bacteriocin production by Lactobacillus plantarum $17.2 \mathrm{~b}$ requires absence of $\mathrm{NaCl}$ and apparently follows a mixed metabolite kinetics. Journal of Biotechnology, 130, 193-201.

Devriese, L. A., Collins, M. D., \& Wirth, R. (1992). The Genus Enterococcus. In A. Balows, H. G. Trüper, M. Dworkin, W. Harder, \& K. H. Schleifer (Eds.), The Prokaryotes (pp. 1465-1481). New York: Springer.

Ennahar, S., Sashihara, T., Sonomoto, K., \& Ishizaki, A. (2000). Class Ila bacteriocins: biosynthesis, structure and activity. FEMS Microbiology Reviews, 24, 85-106.

Feng, G., Guron, G. K. P., Churey, J. J., \& Worobo, R. W. (2009). Characterization of mundticin L, a class Ila anti-Listeria bacteriocin from Enterococcus mundtii CUGF08. Applied and Environmental Microbiology, 75, 5708-5713.

Folquié Moreno, M., Rea, M., Cogan, T., \& De Vuyst, L. (2003). Applicability of a bacteriocin-producing Enterococcus faecium as a co-culture in Cheddar cheese manufacture. International Journal of Food Microbiology, 81, 73-84.

Franciosi, E., Settanni, L., Cavazza, A., \& Poznanski, E. (2009). Biodiversity and technological potential of wild lactic acid bacteria from raw cows' milk. International Dairy Journal, 19, 3-11.

Franz, C. M., Holzapfel, W. H., \& Stiles, M. E. (1999). Enterococci at the crossroads of food safety? International Journal of Food Microbiology, 47, 1-24.

Franz, C. M., Huch, M., Abriouel, H., Holzapfel, W., \& Gálvez, A. (2011). Enterococci as probiotics and their implications in food safety. International Journal of Food Microbiology, 151, 125-140.

Guinane, C., Cotter, P., Hill, C., \& Ross, R. (2005). Microbial solutions to microbial problems; lactococcal bacteriocins for the control of undesirable biota in food. Journal of Applied Microbiology, 98, 1316-1325. 
Jack, R. W., Tagg, J. R., \& Ray, B. (1995). Bacteriocins of Gram-positive bacteria. Microbiological Reviews, 59, 171-200.

Jackson, C. R., Fedorka-Cray, P. J., \& Barrett, J. B. (2004). Use of a genus- and speciesspecific multiplex PCR for identification of enterococci. Journal of Clinical Microbiology, 42, 3558-3565.

Kawamoto, S., Shima, J., Sato, R., Eguchi, T., Ohmomo, S., Shibato, J., et al. (2002). Biochemical and genetic characterization of mundticin KS, an antilisterial peptide produced by Enterococcus mundtii NFRI 7393. Applied and Environmental Microbiology, 68, 3830-3840.

Kim, W. S., Hall, R. J., \& Dunn, N. W. (1997). The effect of nisin concentration and nutrient depletion on nisin production of Lactococcus lactis. Applied Microbiology and Biotechnology, 48, 449-453.

Kim, O. S., Cho, Y. J., Lee, K., Yoon, S. H., Kim, M., Na, H., et al. (2012). Introducing EzTaxon-e: a prokaryotic 16S rRNA gene sequence database with phylotypes that represent uncultured species. International Journal of Systematic and Evolutionary Microbiology, 62, 716-721.

Kuwano, K., Tanaka, N., Shimizu, T., Nagatoshi, K., Nou, S., \& Sonomoto, K. (2005). Dual antibacterial mechanisms of nisin Z against Gram-positive and Gramnegative bacteria. International Journal of Antimicrobial Agents, 26, 396-402.

Leroy, F., \& De Vuyst, L. (1999). Temperature and pH conditions that prevail during fermentation of sausages are optimal for production of the antilisterial bacteriocin sakacin K. Applied and Environmental Microbiology, 65, 974-981.

Leroy, F., \& De Vuyst, L. (2002). Bacteriocin production by Enterococcus faecium RZS C5 is cell density limited and occurs in the very early growth phase. International Journal of Food Microbiology, 72, 155-164.

Moellering, R. C. (1992). Emergence of Enterococcus as a significant pathogen. Clinical Infectious Diseases, 14, 1173-1176.

Mundt, J. O., \& Hammer, J. L. (1968). Lactobacilli on plants. Applied Microbiology, 16, 1326-1330.

Murray, B. E. (1990). The life and times of the Enterococcus. Clinical Microbiology Reviews, 3, 46-65.

Naser, S. M., Thompson, F. L., Hoste, B., Gevers, D., Dawyndt, P., Vancanneyt, M., et al. (2005). Application of multilocus sequence analysis (MLSA) for rapid identification of Enterococcus species based on rpoA and pheS genes. Microbiology, 151, 2141-2150.

Nes, I., Diep, D., Havarstein, L., Brurberg, M., Eijsink, V., \& Holo, H. (1996). Biosynthesis of bacteriocins in lactic acid bacteria. Antonie Van Leeuwenhoek International Journal of General and Molecular Microbiology, 70, 113-128.

Nolan, D. A., Chamblin, D. C., \& Troller, J. A. (1992). Minimal water activity levels for growth and survival of Listeria monocytogenes and Listeria innocua. International Journal of Food Microbiology, 16, 323-335.

Ross, R. P., Morgan, S., \& Hill, C. (2002). Preservation and fermentation: past, present and future. International Journal of Food Microbiology, 79, 3-16.

Saavedra, L., Minahk, C., de Ruiz Holgado, A. P., \& Sesma, F. (2004). Enhancement of the enterocin CRL35 activity by a synthetic peptide derived from the $\mathrm{NH}_{2}$-terminal sequence. Antimicrobial Agents and Chemotherapy, 48, 2778-2781.

Schillinger, U., \& Lücke, F. K. (1989). Antibacterial activity of Lactobacillus sake isolated from meat. Applied and Environmental Microbiology, 55, 1901-1906.
Settanni, L., \& Corsetti, A. (2008). Application of bacteriocins in vegetable food biopreservation. International Journal of Food Microbiology, 121, 123-138.

Settanni, L., Di Grigoli, A., Tornambe, G., Bellina, V., Francesca, N., Moschetti, G., et al (2012). Persistence of wild Streptococcus thermophilus strains on wooden vat and during the manufacture of a traditional Caciocavallo type cheese. International Journal of Food Microbiology, 155, 73-81.

Settanni, L., Massitti, O., Van Sinderen, D., \& Corsetti, A. (2005). In situ activity of a bacteriocin-producing Lactococcus lactis strain. Influence on the interactions between lactic acid bacteria during sourdough fermentation. Journal of Applied Microbiology, 99, 670-681.

Settanni, L., Valmorri, S., Suzzi, G., \& Corsetti, A. (2008). The role of environmental factors and medium composition on bacteriocin-like inhibitory substances (BLIS) production by Enterococcus mundtii strains. Food Microbiology, $25,722-728$.

Thompson, J. D., Gibson, T. J., Plewniak, F., Jeanmougin, F., \& Higgins, D. G. (1997). The CLUSTAL-X windows interface: flexible strategies for multiple sequence alignment aided by quality analysis tools. Nucleic Acids Research, $25,4876-4882$.

Todorov, S., \& Dicks, L. (2004). Effect of medium components on bacteriocin production by Lactobacillus pentosus ST151BR, a strain isolated from beer produced by the fermentation of maize, barley and soy flour. World Journal of Microbiology E Biotechnology, 20, 643-650.

Todorov, S., \& Dicks, L. (2005). Lactobacillus plantarum isolated from molasses produces bacteriocins active against Gram-negative bacteria. Enzyme and Microbial Technology, 36, 318-326.

Todorov, S., Onno, B., Sorokine, O., Chobert, J., Ivanova, I., \& Dousset, X. (1999). Detection and characterization of a novel antibacterial substance produced by Lactobacillus plantarum ST 31 isolated from sourdough. International Journal of Food Microbiology, 48, 167-177.

Van den Berghe, E., De Winter, T., \& De Vuyst, L. (2006). Enterocin A production by Enterococcus faecium FAIR-E 406 is characterised by a temperature- and $\mathrm{pH}$ dependent switch-off mechanism when growth is limited due to nutrient depletion. International Journal of Food Microbiology, 107, 159-170.

Vera Pingitore, E., Todorov, S. D., Sesma, F., \& Franco, B. D. (2012). Application of bacteriocinogenic Enterococcus mundtii CRL35 and Enterococcus faecium ST88Ch in the control of Listeria monocytogenes in fresh Minas cheese. Food Microbiology, 32, 38-47.

Weisburg, W. G., Barns, S. M., Pelletier, D. A., \& Lane, D. J. (1991). 16S ribosomal DNA amplification for phylogenetic study. Journal of Bacteriology, 173, 697-703.

Xian-guo, H., \& Ursula, M. (1994). Antifungal compound from Solanum nigrescens. Journal of Ethnopharmacology, 43, 173-177.

Yang, R., Johnson, M. C., \& Ray, B. (1992). Novel method to extract large amounts of bacteriocins from lactic acid bacteria. Applied and Environmental Microbiology, $58,3355-3359$.

Zendo, T., Eungruttanagorn, N., Fujioka, S., Tashiro, Y., Nomura, K., Sera, Y., et al. (2005). Identification and production of a bacteriocin from Enterococcus mundtii QU 2 isolated from soybean. Journal of Applied Microbiology, 99, 1181-1190. 